\title{
Focus on Formononetin: Anticancer Potential and Molecular Targets
}

\author{
Samantha Kah Ling Ong ${ }^{1}$, Muthu K. Shanmugam ${ }^{1}$, Lu Fan ${ }^{1}$, Sarah E. Fraser ${ }^{2}$, Frank Arfuso ${ }^{3}$, \\ Kwang Seok Ahn ${ }^{4, *(D)}$, Gautam Sethi ${ }^{1, *}$ and Anupam Bishayee ${ }^{2, *}$ \\ 1 Department of Pharmacology, Yong Loo Lin School of Medicine, National University of Singapore, \\ Singapore 117600, Singapore; samantha.ong@u.nus.edu (S.K.L.O.); phcsmk@nus.edu.sg (M.K.S.); \\ phcfanl@nus.edu.sg (L.F.) \\ 2 Lake Erie College of Osteopathic Medicine, Bradenton, FL 34211, USA; SFraser78637@med.lecom.edu \\ 3 Stem Cell and Cancer Biology Laboratory, School of Pharmacy and Biomedical Sciences, Curtin Health \\ Innovation Research Institute, Curtin University, Perth, WA 6102, Australia; frank.arfuso@curtin.edu.au \\ 4 Department of Science in Korean Medicine, Kyung Hee University, 24 Kyungheedae-ro, Dongdaemun-gu, \\ Seoul 02447, Korea \\ * Correspondence: ksahn@khu.ac.kr (K.S.A.); phcgs@nus.edu.sg (G.S.); abishayee@lecom.edu or \\ abishayee@gmail.com (A.B.); Tel.: +82-2-961-2316 (K.S.A.); +65-6516-3267 (G.S.); +1-(941)-782-5950 (A.B.); \\ Fax: +65-6873-7690 (G.S.)
}

Received: 22 March 2019; Accepted: 28 April 2019; Published: 1 May 2019

\begin{abstract}
Formononetin, an isoflavone, is extracted from various medicinal plants and herbs, including the red clover (Trifolium pratense) and Chinese medicinal plant Astragalus membranaceus. Formononetin's antioxidant and neuroprotective effects underscore its therapeutic use against Alzheimer's disease. Formononetin has been under intense investigation for the past decade as strong evidence on promoting apoptosis and against proliferation suggests for its use as an anticancer agent against diverse cancers. These anticancer properties are observed in multiple cancer cell models, including breast, colorectal, and prostate cancer. Formononetin also attenuates metastasis and tumor growth in various in vivo studies. The beneficial effects exuded by formononetin can be attributed to its antiproliferative and cell cycle arrest inducing properties. Formononetin regulates various transcription factors and growth-factor-mediated oncogenic pathways, consequently alleviating the possible causes of chronic inflammation that are linked to cancer survival of neoplastic cells and their resistance against chemotherapy. As such, this review summarizes and critically analyzes current evidence on the potential of formononetin for therapy of various malignancies with special emphasis on molecular targets.
\end{abstract}

Keywords: formononetin; cancer; preclinical models; cell signaling; angiogenesis

\section{Introduction}

Cancer refers to the disease that develops when abnormal cells proliferate uncontrollably, followed by invasion into the surrounding tissues and eventually spreads to the organs or other parts of the body via the circulatory and lymphatic systems [1]. The fundamental process that leads to the development of cancer is the process of continuous, unregulated proliferation of cancer cells, resulting in tumor development [2]. Cancer has claimed the lives of 8.8 million individuals in 2015, making it the second leading cause of death worldwide after cardiovascular diseases $[3,4]$. In the past few decades, numerous treatment methods have been developed against cancer after acquiring a deeper understanding of multiple underlying signals and mechanisms that contribute to the survival and progression of neoplastic cells. These treatment modalities include both adjuvant and neoadjuvant chemotherapy, targeted therapy, immunotherapy, surgery, and radiotherapy. The incidence of cancer 
still remains high, with increasing mortality due to the disease progression despite significant progress in treatment regimens [3,4]. This phenomenon can be largely attributed to the limited effects exhibited by existing cancer therapies and the high cost of treatment, coupled with significant adverse effects [5]. Furthermore, conventional cytotoxic agents usually embody life-threatening toxicities [6]. There have been nearly 500 cases of withdrawal of medicinal products from the market as a result of adverse drug reactions over the past six decades, with the most common reason being hepatotoxicity [7]. In addition, certain cancers, such as breast cancer, can still resurface after a dormant period of 15 years following successful treatment [8], suggesting that there is a need to develop new and safe treatment options that can be proven to be more efficacious.

Natural products and dietary agents have gained enormous popularity over the years to be used in the clinical setting. They can be obtained from plants, microorganisms, or animals and have been used medicinally for decades, usually in complementary and alternative medicine [9]. An example would be Veregen, a topical ointment containing green tea extract sinecatechins, which is used to treat external genital and perianal warts, and the herb Artemisia annua, from which pharmaceutical scientist Tu Youyou managed to isolate artemisinin that is now used as a potent antimalarial drug [10]. These studies indicate the promising use of natural products for future discovery and development of cancer preventive and anticancer drugs. In the past three decades, nearly $80 \%$ of the drugs approved by the United States Food and Drug Administration for cancer therapy contain natural products or imitate their functions [11,12]. Natural products have since then made their appearance and represent a large portion of today's pharmaceutical agents used in cancer therapy, including taxol, vinblastine and camptothecin [13]. Over $60 \%$ of the current anticancer drugs are derived from natural sources [13], and the impetus to discover more natural products for chemotherapy and chemoprevention has become evident in the past decade as more agents are now in clinical trials.

Antitumorigenic activity can be found in compounds with different structural groups, including isoprenoids (including terpenoids and carotenoids), isoflavones, etoposide, and teniposide [5,11,14-35]. They function through various mechanisms, including the induction of apoptosis via DNA cleavage by inhibiting the activity of topoisomerase I or II, mitochondrial permeabilization, inhibiting crucial enzymes in signal transduction (i.e., proteases), cellular metabolism, or by inhibiting tumor-induced angiogenesis $[9,36]$. Certain isoflavones, such as isoliquiritigenin, have been shown to possess antitumorigenic properties, including pro-apoptotic effect on human cancer cells [37]. In recent years, there has been increasing evidence in preclinical and clinical studies that suggest that a dysregulated inflammatory response plays a crucial role in cancer development and may even be a key driver of cancer [38,39].

Chronic inflammation is also one of the hallmarks of cancer, and can drive the development of cancer through increasing the production of pro-inflammatory mediators involved in various signaling mechanisms, including cytokines, chemokines, reactive oxygen species/intermediates, increased expression of oncogenes, cyclooxygenase-2, 5-lipoxygenase, matrix metalloproteinases (MMPs), and pro-inflammatory transcription factors, such as nuclear factor- $\mathrm{KB}(\mathrm{NF}-\mathrm{KB})$, signal transducer and activator of transcription 3 (STAT3), activator protein 1 (AP-1) and hypoxia-inducible factor $1 \alpha$ (HIF-1 $\alpha)$ [38-66]. These factors mediate the basis of cancer progression, such as the proliferation of tumor cells, metastasis, survival, invasion, angiogenesis, chemoresistance and radio-resistance [38,47,61,64,67-71].

Targeting selected transcription factors and pathways increases the sensitivity of cancer cells to chemotherapeutics and radiation, resulting in apoptosis [60]. Furthermore, the use of natural products, such as farnesol, curcumin and celastrol, have been found to significantly enhance the anticancer effects of chemotherapeutics, such as bortezomib and thalidomide, in multiple myeloma $[57,72]$. This suggests that natural products can be used as adjunct cancer therapy. Despite the steady improvement of current anticancer therapeutics, developing novel drugs remains a priority of cancer treatment due to an overwhelming increase in resistance to chemotherapeutic drugs [9,73-76]. With greater knowledge and constant advances in technology, there is a great prospect for safer and more efficacious treatment options for cancer. 
The red clover, Trifolium pratense (family: Fabaceae), is a legume known for its numerous health benefits, and can hold a crucial role in the prevention and management of certain health conditions, including type 2 diabetes, hyperlipidemia and hypertension [77]. It is a perennial herb that is commonly found in Asia, Europe, and North America, and has been traditionally used to treat skin and respiratory conditions, such as eczema, psoriasis, asthma and pertussis [78]. The isoflavones present in red clover have estrogen-like activities and have been subjected to an intense research over the past two decades due to their potential cancer-preventive, cardio-protective and anti-osteoporosis effects [78].

The extract from the red clover plant contains genistein, daidzein, formononetin (biochanin B), and biochanin A. Formononetin [7-hydroxy-3-(4-methoxyphenyl)-4H-1-benzopyran-4-one], (Figure 1), one of the main bioactive components extracted from the red clover, has been found to be the principal compound that contributes the therapeutic effects observed in the extract. It is exclusively produced by the Fabaceae family, and can be extracted from the roots of Astragalus membranaceus, T. pratense and Glycyrrhiza glabra [79]. Since it is structurally similar to 17-estrogen, formononetin's bioactivity mimics the effect of estrogen and this compound is considered to be a phytoestrogen [80].

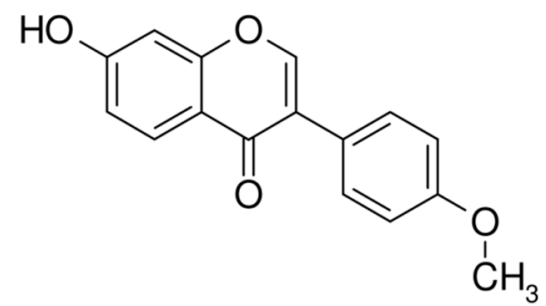

Figure 1. The chemical structure of formononetin.

Formononetin has shown beneficial effects in clinical trials for menopausal relief $[81,82]$, reduction in bone loss [83], and improved arterial compliance [84]. Formononetin has been used clinically in China, in traditional medicine, as one of the fundamental herbs for treating carcinomas due to its protective effects against certain malignant tumors [85]. Formononetin has become the subject of intense research over the past decade due to its estrogenic effects and antitumorigenic properties. This review will summarize and critically analyze current evidence on the potential of formononetin for anticancer therapy with special emphasis on molecular targets.

\section{Toxicity and Pharmacokinetics of Formononetin}

A water-soluble derivative of formononetin, formononetin-3'-sulphonate (Sul-F, $\mathrm{C}_{16} \mathrm{H}_{12} \mathrm{O}_{7} \mathrm{SNa}$ ), has been shown to provide significant neuro- and cardio-protective effects both in vitro and in vivo [86,87]. Pro-estrogenic isoflavones, such as formononetin, can potentially be converted to more potent phytoestrogens in the human body. Incubation of formononetin in human liver microsomes caused demethylation, resulting in the production of formononetin derivatives and metabolites, including daidzein [88]. Due to the fact that formononetin is a naturally occurring isoflavone and phytoestrogen, it is associated with estrogen receptor (ER) binding. Phytoestrogens, especially isoflavones, can be classified as endocrine disruptors and are known to modify or interfere with the endocrine function [80].

Formononetin and its metabolites can significantly enhance pro-inflammatory cytokines and induce an allergic immune response. Interleukin-4 (IL-4) is closely associated with the CD4 ${ }^{+} \mathrm{T}$ helper cells and EL4 T lymphoma cells (Mus musculus). An increase in IL-4 production is observed upon administration of formononetin, daidzein, and equol due to an elevation in the activation of activator protein 1 (AP-1) via the phosphoinositide 3-kinase (PI3K)/protein kinase C (PKC)/p38 mitogen activated protein kinase (MAPK) signaling pathway. This suggests that formononetin and its metabolites may potentially cause allergic responses through amplifying the production of IL-4 in T-cells [89]. Hence, it may be a reasonable approach to restrict or limit the usage of formononetin in order to prevent allergic responses. 


\section{In Vitro Anticancer Pharmacological Properties of Formononetin}

\subsection{Antiproliferative Effects}

The anticancer potential of formononetin has been explored in numerous in vitro models as shown in Table 1. First and foremost, formononetin showed potential in inhibiting tumor growth and proliferation. Uncontrolled proliferation is one of the primary hallmarks of cancer and represents one of the most prominent factors associated with malignancy. This antiproliferative effect of formononetin has been observed in multiple cancer models and is one of the main anticancer properties of formononetin. As compared to other isoflavones, formononetin has been proven to possess the greatest antiproliferative activity [90]. The antiproliferative property of formononetin has been observed in ER-positive breast cancer cells, such as MCF-7 and T-47D [91,92], and displayed minimal effect against ER-negative breast cancer cells, namely MDA-MB-231 and MDA-MB-435 [93]. It also demonstrated antiproliferative effects against prostate cancer (PC-3, DU-145 and LNCaP) [94,95], non-small cell lung cancer (A549 and NCI-H23) [96], cervical cancer (HeLa) [97], bladder cancer (T24) [98], osteosarcoma (U2OS), ovarian cancer (ES2 and OV90) [99], glioma (C6), and colorectal cancer cells (HCT-116, SW1116 and RKO) [37,85].

For most cell lines, formononetin has been found to possess a concentration- and time-dependent effect against tumor proliferation [85,94,96,98]. Antiproliferative effects of formononetin were also demonstrated in cytokine-induced cancer models, such as multiple myeloma, where formononetin attenuated the expression of inflammatory cytokines, including tumor necrosis factor- $\alpha$ (TNF- $\alpha$ ), transforming growth factor- $\beta 1$ (TGF- $\beta 1$ ), interleukin-6 (IL-6), and interleukin- 8 (IL-8) by downregulating hypoxia-inducible factor $1 \alpha(\mathrm{HIF}-1 \alpha)$ [39,100] and nuclear factor-kB (NF-kB) [101]. Most studies conducted thus far indicate that formononetin has been able to prevent the proliferation of tumor cells without causing serious adverse effects as compared to other chemotherapeutic drugs.

\subsection{Proapoptotic Effects}

For progression of abnormal cells into cancerous ones, it is crucial that the apoptosis pathway is hijacked to allow promotion of growth and development of the damaged or abnormal cells. Cancer cells have the ability to evade the apoptotic checkpoints, allowing them to proliferate uncontrollably [102]. As a result, the proapoptotic property of formononetin elevates its potential to be used as an anticancer agent in cancer therapy. However, the underlying mechanisms of formononetin that promote cell apoptosis differ among different cell lines as well as cancer models. Apoptosis observed in cells can be classified into two different stages - early and late apoptosis—which can be differentiated through the presence of propidium iodide [102]. Formononetin largely elevated the proportion of early apoptotic cells in DU-145 prostate and U2SO osteosarcoma cell lines, and was found to be dose-dependent for prostate PC-3 cells $(25-100 \mu \mathrm{M})$ [103-105].

The influence of formononetin on apoptosis of different cancer cell lines may involve the upregulation of specific transcription factors. The apoptotic mechanism in prostate DU-145 cells is activated by upregulating dexamethasone-induced retrovirus associated DNA sequences (Ras)-related protein 1 (maximum for $48 \mathrm{~h}$ before decreasing rapidly after) and Bcl-2-associated protein (Bax), and simultaneously reducing B-cell lymphoma 2 (Bcl-2) levels, thereby causing the DU-145 cells to display morphological changes indicative of the early apoptotic stage, and trigger apoptosis via the mitochondrial apoptotic pathway [106]. On the contrary, high concentrations of formononetin $(>12.5 \mu \mathrm{M})$ have been found to effectively inhibit proliferation and trigger apoptosis of PC-3 prostate cancer cells by inhibiting the insulin-like growth factor 1 (IGF-1) receptor androgen-independent pathway [104]. T24 human bladder cancer cells displayed morphological changes of apoptosis when treated with formononetin, and there was a significant reduction in the expression of miR-21 and phosphorylated protein kinase B (AKT). In addition, phosphatase and tensin homolog (PTEN), a notable tumor suppressor gene, was upregulated in T24 cells after formononetin treatment, which suppressed uncontrolled tumor proliferation [98]. Furthermore, a study by Zhang and colleagues [107] suggested that formononetin did not elicit toxic effects on non-cancerous cell lines, indicating that it may be a safe choice to halt cancerous cell growth. 
Table 1. In vitro anticancer effects of formononetin.

\begin{tabular}{|c|c|c|c|c|}
\hline Cancer Type/Cell Line Used & Concentration & Anticancer Effect & Mechanisms of Action & References \\
\hline \multicolumn{5}{|c|}{ Bladder cancer } \\
\hline T24 cell line & $50-200 \mu \mathrm{M}$ & $\begin{array}{l}\text { Antiproliferative } \\
\text { Anti-invasion }\end{array}$ & $\uparrow$ Apoptosis; $\uparrow$ PTEN; $\downarrow$ miR-21; $\downarrow$ pAKT & [98] \\
\hline MCF-7 cell line & $30-100 \mu \mathrm{M}$ & Antiproliferative & $\uparrow$ Apoptosis; $\uparrow$ G0/G1 cell cycle arrest; $\downarrow$ IGF-1/IGFR-PI3K/AKT pathway & [91] \\
\hline \multicolumn{5}{|c|}{ Breast cancer } \\
\hline ER-positive MCF-7 cells and T47D cell & $25-100 \mu \mathrm{M}$ & Antiproliferative & $\uparrow$ Apoptosis; $\downarrow$ p38MAPK pathway & [92] \\
\hline ER-positive MCF-7 cells and T47D cell & $25-100 \mu \mathrm{M}$ & Antiproliferative & $\uparrow$ Caspase-3; \IGF1R; \miR375 & [93] \\
\hline $\begin{array}{c}\text { MDA-MB-231 } \\
4 \mathrm{TI}\end{array}$ & $2.5-40 \mu \mathrm{mol} / \mathrm{L}$ & Antiproliferative & $\downarrow$ MMP-2; $\downarrow$ MMP-9, $\downarrow$ TIMP1; $\downarrow$ TIMP2; $\downarrow$ PI3K/AKT pathway & [108] \\
\hline \multicolumn{5}{|l|}{ Cervical cancer } \\
\hline HeLa cells & Not available & Antiproliferative & $\uparrow$ Apoptosis; $\downarrow$ PI3K/AKT pathway; $\downarrow$ ERK pathway & [97] \\
\hline \multicolumn{5}{|c|}{ Colon cancer } \\
\hline LoVo & $50 \mu \mathrm{M}$ & Anti-invasion & $\uparrow$ Apoptosis; $\downarrow$ VEGF; $\downarrow$ MMP & [109] \\
\hline \multicolumn{5}{|c|}{ Colorectal cancer } \\
\hline HCT116 cell line & $6.25-200 \mu \mathrm{M}$ & Antiproliferative & $\uparrow$ Apoptosis; $\uparrow$ Bax; $\uparrow$ NAG-1; $\downarrow$ Bcl-2; $\downarrow$ Bcl-xL & [37] \\
\hline $\begin{array}{l}\text { SW1116 cell line } \\
\text { HCT116 cell line }\end{array}$ & $20-200 \mu \mathrm{M}$ & Antiproliferative & $\uparrow$ miR-149; $\downarrow$ EphB3; $\downarrow$ PI3K/AKT pathway; $\downarrow$ STAT3 pathway & [85] \\
\hline RKO cell line & $20-80 \mu \mathrm{M}$ & Antiproliferative & $\uparrow$ Apoptosis; $\downarrow$ ERK pathway & [101] \\
\hline \multicolumn{5}{|c|}{ Glioma } \\
\hline Glioma C6 cell line & $20-320 \mu \mathrm{M}$ & Antiproliferative & $\uparrow$ Apoptosis; $\uparrow$ Bax; $\uparrow$ cleaved caspase- 3 \& caspase-9; $\downarrow$ Bcl-2; $\downarrow$ MMP-2; $\downarrow$ MMP-9 & [110] \\
\hline \multicolumn{5}{|c|}{ Glioblastoma } \\
\hline U87MG cell line U251MG cell line T98G cell line & $50-200 \mu \mathrm{M}$ & Antiproliferative & $\downarrow$ HDAC5; $\downarrow$ doxorubicin-induced EMT & [111] \\
\hline \multicolumn{5}{|c|}{ Multiple myeloma } \\
\hline U266 cell line & $5-60 \mu \mathrm{M}$ & Antiproliferative & $\downarrow$ HIF- $1 \alpha$; $\downarrow$ inflammatory cytokines; $\downarrow$ AKT pathway & [100] \\
\hline \multicolumn{5}{|c|}{ Nasopharyngeal carcinoma } \\
\hline $\begin{array}{l}\text { CNE1 cell line } \\
\text { CNE2 cell line }\end{array}$ & $5-40 \mu \mathrm{M}$ & $\downarrow$ Cell viability & $\uparrow$ Apoptosis; $\downarrow$ PI3K/AKT pathway; $\downarrow$ ERK pathway & [112] \\
\hline
\end{tabular}


Table 1. Cont

\begin{tabular}{|c|c|c|c|c|}
\hline Cancer Type/Cell Line Used & Concentration & Anticancer Effect & Mechanisms of Action & References \\
\hline \multicolumn{5}{|c|}{ Non-small cell lung cancer } \\
\hline $\begin{array}{l}\text { A549 cell line } \\
\text { NCI-H23 cell line }\end{array}$ & $100-200 \mu \mathrm{M}$ & Antiproliferative & $\begin{array}{c}\uparrow \text { Apoptosis; } \uparrow \text { caspase- } 3 ; \uparrow B a x ; \\
\downarrow \text { Bcl-2; } \uparrow \text { P21; } \downarrow \text { cyclin A; } \downarrow \text { cyclin D1; } \uparrow \text { G1 cell cycle arrest; }\end{array}$ & [96] \\
\hline \multicolumn{5}{|c|}{ Osteosarcoma } \\
\hline $\mathrm{U} 2 \mathrm{OS}$ & $20-80 \mu \mathrm{M}$ & Antiproliferative & $\begin{array}{c}\uparrow \text { Apoptosis; } \uparrow \text { caspase-3; } \uparrow \text { Bax; } \downarrow \text { Bcl-2; } \downarrow \text { PI3K/AKT pathway; } \\
\downarrow \text { ERK pathway }\end{array}$ & [90] \\
\hline \multicolumn{5}{|c|}{ Ovarian cancer } \\
\hline $\begin{array}{l}\text { ES2 cell line } \\
\text { OV90 cell line }\end{array}$ & $20-40 \mu \mathrm{M}$ & Antiproliferative & $\uparrow$ Apoptosis; $\uparrow \mathrm{G} 0 / \mathrm{G} 1$ cell cycle arrest & [99] \\
\hline \multicolumn{5}{|c|}{ Prostate cancer } \\
\hline $\begin{array}{l}\text { LNCaP cell line } \\
\text { PC-3 cell line }\end{array}$ & $20-80 \mu \mathrm{M}$ & Antiproliferative & $\uparrow$ Apoptosis; $\uparrow$ G1 cell cycle arrest; $\downarrow$ AKT/cyclin D1/CDK4; $\downarrow$ ERK1/2 pathway & [94] \\
\hline $\begin{array}{l}\text { PC-3 cell line } \\
\text { DU-145 cell line }\end{array}$ & $10-100 \mu \mathrm{M}$ & Antiproliferative & $\uparrow$ Apoptosis; $\uparrow$ G1/S cell cycle arrest; $\downarrow$ IGF/IGFR1 pathway & [95] \\
\hline PC-3 cell line & $25-100 \mu \mathrm{M}$ & Antiproliferative & $\uparrow$ Apoptosis; $\downarrow$ IGF/IGFR1 pathway & [104] \\
\hline DU-145 cell line & $6.25-200 \mu \mathrm{M}$ & Antiproliferative & $\uparrow$ Apoptosis; $\uparrow$ Bax; $\uparrow$ RASD1; $\uparrow$ caspase-3; $\uparrow$ PARP; $\downarrow$ Bcl-2 & [106] \\
\hline PC-3 cell line & $25-100 \mu \mathrm{M}$ & Antiproliferative & $\uparrow \mathrm{Bax} / \mathrm{Bcl}-2$ ratio; $\downarrow$ p38MAPK/AKT pathway & [107] \\
\hline
\end{tabular}

AKT, protein kinase B; Bax, Bcl-2-associated protein; Bcl-2, B-cell lymphoma 2; Bcl-xL, B-cell lymphoma-extra-large; CDK, cyclin-dependent kinase; EMT, epithelial-mesenchymal transition; ERK, extracellular signal regulated kinase; EphB3, ephrin type-B receptor 3; HDAC5, histone deacetylase 5; HIF-1 $\alpha$, hypoxia-inducible factor 1 $\alpha$; IGF-1, insulin-like growth factor 1; IGF-1R, insulin-like growth factor 1 receptor; MAPK, mitogen-activated protein kinase; miR, microRNA; MMP, matrix metalloproteinase; NAG-1, NSAID-activated gene; PI3K, phosphatidylinositol 3-kinase; PTEN, phosphatase and tensin homolog; p21, cyclin-dependent kinase inhibitor; PARP, poly-ADP ribose polymerase; RASD, ras-related dexamethasone induced; STAT3, signal transducer and activator of transcription 3; TIMP, tissue inhibitor of metalloproteinase; VEGF, vascular endothelial growth factor. 
One of the primary factors associated with cell apoptosis is the Bax and Bcl-2 protein levels, usually coupled with the AKT and extracellular signal regulated kinase (ERK) pathway. Bax protein is crucial for apoptosis in normal cells to prevent excessive proliferation and possible tumor formation. However, Bcl-2 functions in the opposite manner: enhancing cell survival by suppressing apoptosis [113]. Formononetin treatment reduced $\mathrm{Bcl}-2$ protein levels and upregulated the pro-apoptotic proteins, such as Bax and caspase-3, thereby increasing the Bax/Bcl-2 ratio and inducing apoptosis. This effect was observed in several cancers, including prostate cancer (PC-3) [107], osteosarcoma (U2OS) [105], non-small cell lung cancer (A549 and NCI-H23) [96], and colon carcinoma (HCT-116) [37], and was sometimes coupled with caspase and phosphorylation activity. In PC-3 cells, increased phosphorylation of $\mathrm{p} 38$ and blocked AKT phosphorylation accompanied the growth in the Bax/Bcl-2 ratio to induce apoptosis [107]. An elevated activation and cleavage of caspase-3 was observed in A549 and NCI-H23 non-small cell lung cancer cell lines [96], and antiapoptotic proteins Bcl-2 and Bcl-xL were downregulated in HCT-116 colon cancer cells, along with caspase activation [37]. Furthermore, the upstream regulator and a novel pro-apoptotic protein, non-steroidal anti-inflammatory drug (NSAID)-activated gene (NAG-1) was found to be overexpressed in formononetin-treated HCT-116 cells, potentially promoting the apoptotic effects of formononetin; however, it failed to induce phase-specific cell cycle arrest [37]. In a recent study formononetin was found to inhibit the growth of osteogenic sarcoma U2OS cells and induce apoptosis by modulating the intracellular miR-375/ER $\alpha$-PI3K/AKT signaling pathway [114].

Studies conducted thus far indicate that formononetin supports the apoptotic process of cancer cells through intrinsic pathways, but the mechanism and pathways may differ between different cancers. The most evident pathways suppressed by formononetin to induce apoptosis are the PI3K/AKT and the extracellular signal regulated kinase (ERK) pathways, which are the main regulatory pathways found dysregulated in many cancers. These pathways regulate the cell cycle and transmit signals from the surface of the cell to the nuclear DNA $[115,116]$. Some examples include cervical cancer (HeLa), osteosarcoma (U2OS) [90,105], and colorectal cancer (RKO) [101]. Other studies showed that formononetin successfully promoted apoptosis in prostate cancer (DU-145 and PC-3) [104,106,107], breast cancer (MCF-7 and MDA-MB-231) [92,93,108], non-small cell lung cancer (A549 and NCI-H23) [96], colon cancer (HCT116 and SW1116) [37,85], and nasopharyngeal carcinoma (CNE1 and CNE2) [112] via modulation of aforementioned pathways. Formononetin inactivated the MAPK signaling pathway, causing apoptosis in MCF-7 breast cancer cells and increased expression levels of Bax in LNCaP and PC-3 prostate cancer cells, leading to apoptosis [94]. Another commonly dysregulated pathway in cancer is the STAT3 signaling pathway. Emerging evidence suggests that abnormal STAT3 signaling drives the initiation and progression of human cancers through the inhibition of apoptosis and driving multiple pro-oncogenic functions $[57,66,72,117-120]$. Formononetin has been found to suppress fibroblast growth factor 2 (FGF2)-induced STAT3 activation, successfully suppressing multiple myeloma, leukemia, lymphoma and solid tumors that display constitutive STAT3 activation [121]. Furthermore, formononetin has been found to elicit greater antiproliferative and proapoptotic activity as compared to other isoflavones, such as calycosin [90].

\subsection{Induction of Cell Cycle Arrest}

Treatment of various cancer cell lines using formononetin has been shown to attenuate cancer cell proliferation via cell cycle arrest. Formononetin has been demonstrated to be highly effective in suppressing the oncogenic PI3K/AKT pathway [122-132] and inducing cell cycle arrest in numerous cell lines, including breast cancer (MCF-7), colorectal cancer (HCT-116 and SW1116) [85], non-small cell lung cancer [96], and prostate cancer (PC-3 and DU-145) [95]. Formononetin can induce cell cycle arrest at the G0/G1 phase by modifying the level of expression of cell cycle arrest-associated proteins and growth factors, as observed in DU-145 and PC-3 prostate cancer cells [95], A549 and NCI-H23 lung adenocarcinoma cells [96], ES2 and OV90 ovarian cancer cells [99], and MCF-7 breast cancer cells [91]. In non-small cell lung cancer, proliferation of A549 and NCI-H23 cells was significantly inhibited with 
treatment with formononetin. In human non-small cell lung cancer cells, formononetin induced cell cycle arrest in the G1-phase and promoted apoptosis via increasing p21 expression and reducing cyclin A and D1 expression in a time- and concentration-dependent manner [96].

Similarly, formononetin induced G1 arrest in PC-3 and DU-145 prostate cancer cells by downregulating cyclin D1, protein kinase B (AKT), and cyclin dependent kinase 4 (CDK4) in a concentration-dependent manner, and this phenomenon was observed to be more significant in PC-3 cells than DU-145 cells [95]. Inactivation of AKT facilitated the phosphorylation of glycogen synthase kinase-3 $\beta$ (GSK-3 $\beta$ ), which, coupled with the reduction of cyclin D1, can deter progression into the G1/S phase [133]. Likewise, formononetin induced G0/G1 cell cycle arrest in MCF-7 cells by inactivating the IGF-1/IGFR-PI3K/AKT pathway [91]. On the contrary, cell cycle arrest in SW1116 and HCT-116 colon carcinoma cells at the G0/G1 checkpoint was induced through the suppression of cyclin D1 in a concentration-dependent manner, without changes in the expression levels of cyclin B1, which propagated the number of cells undergoing G1 phase cell cycle arrest to $79.7 \%$ upon treatment with $100 \mu \mathrm{M}$ formononetin [85]. Collectively, these results suggest that the administration of formononetin modulated the expression levels of crucial cell cycle regulators through different pathways, consequently leading to cell cycle arrest at the G1 phase and apoptosis in various cancer cell lines.

\subsection{Antioxidant Effects}

Formononetin has been investigated for its antioxidant properties and is known for being a potent and effective natural antioxidant capable of protecting cells from most free radicals. This is a crucial property of formononetin that may support its use as an anticancer agent because free radicals can lead to cancer development [134]. Formononetin is also the most effective isoflavone in inhibiting lipid peroxidation as it possesses the strongest antioxidant activity [135].

\subsection{Angiogenesis-Modulating Effects}

Tumor angiogenesis is an essential pathway for the development and progression of malignant tumors [136], and studies have shown that the PI3K pathway may hold a vital role in this process [137]. It is a crucial process that leads to the growth and spread of cancer. The effect of formononetin on angiogenesis differs for different cancers. In one study, formononetin downregulated the expression of key pro-angiogenic factors, such as vascular endothelial growth factor (VEGF) and matrix metalloproteinases (MMPs), in LoVo human colorectal adenocarcinoma cells and reduced xenografted tumor size and the number of proliferating cells in the tumor tissues with decreased serum VEGF level [109]. MMP-2 and MMP-9 are known to be directly associated with tumor angiogenesis [138].

The most well-known pathway involved in antiangiogenic therapies currently under evaluation in clinical trials targets the VEGF pathway. However, there is a chance of the tumor acquiring resistance to the VEGF-targeted therapy by shifting to other angiogenesis mechanisms [121], therefore rendering the antiangiogenic treatment ineffective. Consequently, there is a need to develop alternative therapeutic agents that inhibits other non-VEGF angiogenic pathways. Other angiogenesis inducers, apart from VEGF, are the fibroblast growth factors basic fibroblast growth factor (b-FGF/FGF-2), making them a potential drug target for cancer, such as melanoma $[137,139]$. Formononetin has been found to be a novel FGF receptor 2 inhibitor as it suppressed the sprouting of FGF2-induced micro-vessel in rat aortic rings and angiogenesis, specifically targeting the FGF receptor 2-mediated AKT signaling pathway, resulting in the attenuation of tumor growth and angiogenesis [121]. As a result, formononetin could be investigated in future studies as an angiogenesis inhibitor through targeting FGFs.

\subsection{Metastasis-Regulatory Effects}

When highly metastatic MDA-MB-231-luc and 4TI breast cancer cells were exposed to formononetin, no significant difference in the cell viability was observed as compared to untreated cells [108]. However, treatment with formononetin $(2.5-40 \mu \mathrm{mol} / \mathrm{L})$ reduced the migration of MDA-MB-231 and 4TI cells in a 
concentration-dependent manner. Furthermore, formononetin reduced the invasion of MDA-MB-231 and 4T1 cells. Invasiveness of metastatic cancer was also attenuated in the LoVo human colon cancer cell line [109]. This phenomenon may have been due to the reduced expression levels of MMPs. MMP-2 and MMP-9 levels were reduced concentration-dependently with formononetin treatment, and formononetin elevated the expression levels of tissue inhibitor of MMP-1 and MMP-2, which are negative regulators of MMPs [108], suggesting that formononetin has the ability to influence the expression levels of proteins and genes associated with proteolytic activation.

\subsection{Anti-Inflammatory Effects}

One of the hallmarks of cancer development is chronic inflammation. It can drive tumor progression by regulating proliferation, invasion, metastasis, angiogenesis, chemoresistance, and radio-resistance of tumor cells $[1,2,38,60,61,102]$. NF- $\mathrm{kB}$, a pro-inflammatory transcription factor, is associated with the inflammation and suppression of apoptosis, and is a key driver of different cellular processes in multiple cancer models $[21,50,60,62,64]$. NF- $\mathrm{kB}$ can translocate into the nucleus and activate numerous genes that are involved in multiple processes crucial for multistage carcinogenesis, including proliferation, invasion, and angiogenesis, upon activation by cytokines or chemotherapeutic agents. As a result, chemotherapeutics that can potentially inhibit NF- $\mathrm{KB}$ have a significant role in anticancer therapy $[5,12,21,38,50,58,60,62,102,129]$. Formononetin demonstrated an inhibitory effect on NF- $\mathrm{B} B$ activation, and NF- $\mathrm{KB}$ is a significant transcription factor for the induction of nitric oxide synthase to decrease the production of nitric oxide in vitro [140]. The inhibition of NF- $k B$ suggests the potential crucial and therapeutic effect that formononetin may have in protecting against inflammation, which may result in cancer development. Overall, the important oncogenic and pro-inflammatory pathways affected by formononetin have been depicted in Figure 2 .

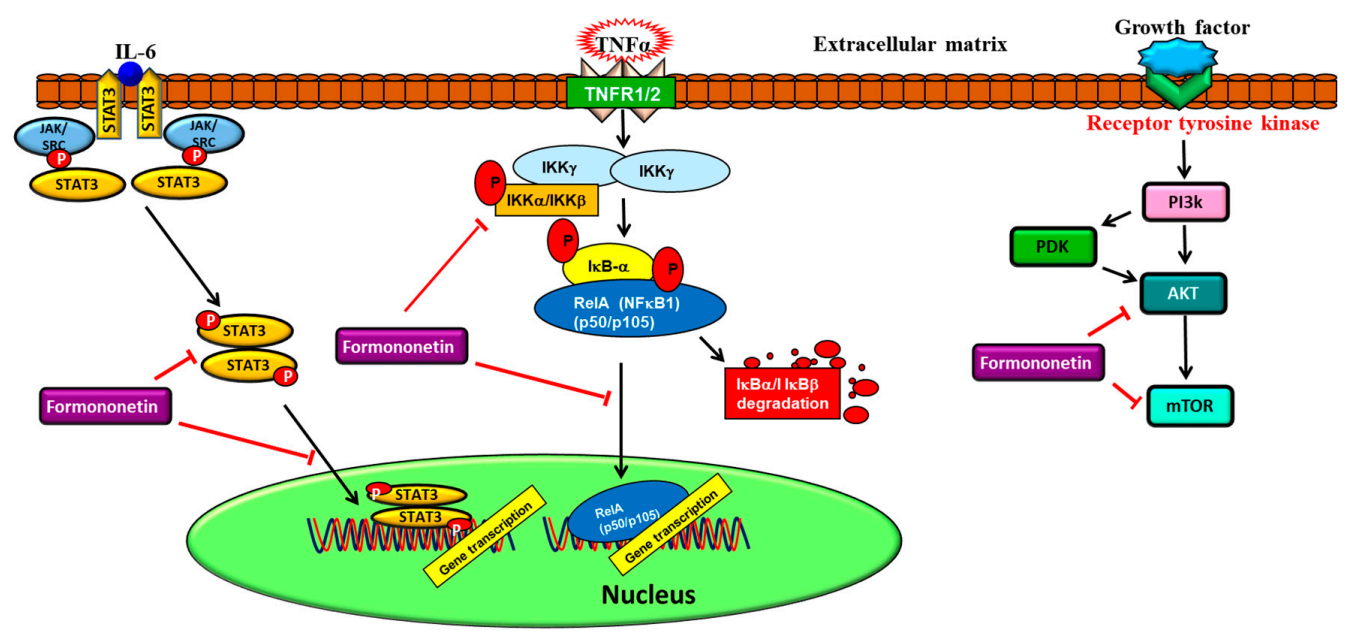

Figure 2. Formononetin regulates major oncogenic pathways involved in cancer progression. $\perp$, inhibition/downregulation; $\uparrow$ upregulation/activation.

\subsection{Combinatorial Studies with Selected Chemotherapeutics}

Previous clinical studies suggest that polysaccharides obtained from Astragalus plants can counteract the adverse effects of chemotherapeutic drugs, including a significant reduction of myelosuppression in cancer patients [141]. In addition to the antiproliferative and proapoptotic properties of formononetin, the expression level of p53 was concentration-dependently upregulated after treatment with formononetin through increased phosphorylation of p53 at Ser15 and Ser20, enhancing its transcriptional activity [96]. For example, formononetin demonstrated synergy when coupled with the use of other chemotherapeutic drugs. Temozolomide (TMZ) is an oral chemotherapy drug often used in the treatment for certain brain cancers, such as glioblastoma multiforme. However, TMZ is a chemotherapeutic drug that is known to causes adverse side effects, including hematologic complications 
and both intrinsic and acquired resistance [110,142]. Although results found that both formononetin and TMZ alone were sufficient to inhibit the growth of $\mathrm{C} 6$ glioma cells concentration-dependently, when formononetin is used in combination with $\mathrm{TMZ}$, it displayed a synergistic effect on $\mathrm{C} 6$ cells. The combination of both drugs increased Bax protein expression and cleaved caspase- 3 and caspase- 9 , attenuated Bcl-2 expression, and promoted tumor cell apoptosis [110]. Furthermore, the drug combination prevented the migration of $\mathrm{C} 6$ glioma cells due to the down-regulated expression of MMP-2 and MMP-9. This suggests the potential use of formononetin as a combination drug during chemotherapy or as a post-operative adjuvant therapy to curb the adverse effects displayed by other chemotherapeutic drugs, such as TMZ. Co-treatment consisting of formononetin with synthetic inhibitors for ovarian cancer, such as LY294002 (PI3K inhibitor) or U0126 [mitogen activated protein kinase kinase (MEK) inhibitor], further prevented the proliferative effects on ovarian cancer cells (ES2 and OV90), thus increasing the occurrence of apoptosis in both cell lines [99].

Furthermore, a potent chemotherapy drug doxorubicin has been identified to induce epithelial-mesenchymal transition (EMT) in glioma cells via elevated expression of vimentin and reduced expression of E-cadherin in U87MG glioma cells [111]. Numerous studies have suggested the important role that EMT holds in carcinogenicity, metastasis, progression, and acquired chemoresistance $[129,143-146]$. Formononetin has been proven to be able to sensitize glioma cells to doxorubicin, and combination therapy using doxorubicin and formononetin is able to successfully reverse the induction of EMT by doxorubicin. In addition, histone deacetylase 5 (HDAC5) has been identified to enhance glioma cell proliferation, and doxorubicin-treated glioma cells have been identified to have significantly increased HDAC5 levels. However, co-treatment with formononetin reduced the expression of HDAC5 in glioma cells. These results implied that co-treatment with formononetin and other chemotherapeutic drugs, such as doxorubicin, potentially sensitizes cancer cells, such as glioma cells, through the prevention of EMT and the inhibition of HDAC5 [111]. This further suggests that formononetin could be considered as an adjuvant agent with existing chemotherapeutic drugs.

\subsection{Novel Semi-Synthetic Hybrids of Formononetin}

Several new bioactive derivatives of formononetin have been shown to have potent anti-cancer activity. Ren et al., 2012 showed that formononetin nitrogen mustard derivative (IC50-3.8 $\mu \mathrm{M}$ ) exhibited potent antitumor activity against colorectal HCT-116 cells and was associated with G2/M phase cell cycle arrest and induction of apoptosis [147]. In another study, formononetin-dithiocarbamate hybrid (IC50-1.97 $\mu \mathrm{M}$ ) inhibited androgen independent prostate cancer PC3 cell growth and induced apoptosis by modulating the MAPK and wingless (Wnt) signaling pathway [148]. Several lines of evidence suggest that epidermal growth factor receptor (EGFR) is an attractive target for non-small cell lung cancer (NSCLC) therapy. Lin et al 2017 reported on a new series of formononetin derivatives following the binding model of lapatinib to EGFR. Formononetin derivatives exhibited potent anti-proliferative activity against triple negative breast cancer MDA-MB-231 cells and induced apoptosis by down-regulating multiple EGFR/PI3K/Akt/Bcl-2-associated death promoter (Bad), EGFR/ERK and EGFR/PI3K/Akt/ $\beta$-catenin signaling pathways in breast cancer cells [149]. In another study a formononetin 7-phosphoramidate derivative significantly induced early apoptosis in HepG-2 cells [150]. In a recent study by Chengli et al. [151] three new derivatives of formononetin were shown to inhibit the growth, invasion and migration of A549 lung cancer cells. Furthermore, Bohong et al. [152] demonstrated that multiwalled carbon nanotube-formononetin (MWCNT-FMN) composite for sustained delivery induced apoptosis by activating reactive oxygen species (ROS) production in cervical carcinoma HeLa cells.

\section{In Vivo Anticancer Pharmacological Activities of Formononetin}

The anticancer potential of formononetin has been demonstrated in numerous in vivo models as shown in Table 2. First, formononetin has demonstrated the potential to inhibit tumor proliferation in various murine models of cancers. As compared to controls, formononetin is able to significantly and 
dose-dependently inhibit local tumor growth in nude mice bearing MCF-7 human breast cancer [91]. The weight of the tumor in the formononetin-treated group was reduced significantly when compared to the control, and this was substantiated with a reduction of $39.6 \%$ in tumor weight. Similar effects have been observed using human colorectal cancer cell lines. HCT-116 nude mice xenografts (CCL-247) treated with formononetin exhibited a large reduction in tumor volume and the number of proliferating cells as compared to the vehicle-treated group [109]. Mortality and significant changes in body weight were not observed in the formononetin-treated HCT-116 nude mice xenografts, indicating that formononetin displayed tolerable toxicity while being able to significantly reduce tumor size and mass in vivo. This observation was substantiated with comparable white blood cell counts between the formononetin-treated and control group, suggesting that formononetin did not exhibit neutropenic effects in preclinical models, unlike other common chemotherapeutic drugs [109]. Furthermore, formononetin has been proven to successfully inhibit the growth of tumors in vivo through targeting the TNF- $\alpha /$ NF- $\mathrm{KB}$ pathway in colorectal tumor bearing nude mice [101], and both tumor weight and volume decreased dose-dependently after treatment with formononetin.

The antitumor potential of formononetin is also observed in human multiple myeloma xenografts in nude mice, with a decrease in Ki-67 expression levels in tumor tissues [49]. Oxidative stress induced through formononetin treatment impeded the expression of phosphorylated STAT3 and STAT5 through the STAT3 and STAT5 signaling axis by successfully removing the binding ability of both transcription factors; thereby reversing their activation and consequently suppressing tumor growth in multiple myeloma [49]. Similarly, the antiproliferative effect was also observed in vivo in U2OS osteosarcoma and PC-3 and DU-145 prostate cancer nude mouse xenografts in a dose-dependent manner through a significant reduction in tumor weight $[95,105]$. This further affirms the potential application of formononetin as a cancer therapeutic agent. However, it is important to note that varying concentrations of phytoestrogens may exude different effects on the proliferative and apoptotic properties of different cancer models.

In vivo mouse metastasis models were used to study the inhibitory effects of formononetin on metastatic breast cancer cells (MDA-MB-231-luc and 4T1) for lung metastasis [108]. Formononetin is able to successfully diminish the development of lung metastasis in mouse xenografts with metastatic breast cancer, which suggests that formononetin may possess antimigration and invasion properties on breast cancer cells and therefore, can increase survival time in preclinical models. This is an important finding that could promote the use of formononetin in clinical settings for chemotherapy because it plays a protective role against breast cancer metastasis.

Formononetin has been investigated for its ability to exhibit antioxidant properties in in vivo models. Antioxidant and estrogenic properties are important factors that could catalyze the development of cancers as they are found to be involved in oxidative damage to the cellular macromolecules. Several antioxidant enzymes, including superoxide dismutase (SOD), catalase (CAT), and glutathione peroxidase (GSH-Px), are essential to counter the reactive oxygen species in vivo [153]. Preclinical studies using ovariectomized mice supported the use of formononetin as a potent free radical scavenging molecule that can prevent lipid peroxidation, which is a crucial factor in the progression of cancer [154].

The pharmacological property of formononetin in vivo is dependent on the level of estrogen present, which can be proestrogenic or antiestrogenic [92]. As previously mentioned, free radicals are highly reactive chemicals that can damage several major components of cells, especially the DNA, playing a pivotal role in the development of cancer. The oxidative effects of formononetin were monitored through the levels of SOD, GSH-Px, CAT, and malondialdehyde (MDA). A high and low formononetin intake for 6 months was found to increase uterine weight and the levels of SOD, GSH-Px, and CAT, and reduced MDA content in preclinical conditions, suggesting that formononetin displayed obvious antioxidant and estrogenic effects in in vivo conditions, and the estrogenic property of formononetin is not dose-dependent [153]. 
Table 2. In vivo anticancer effects of formononetin.

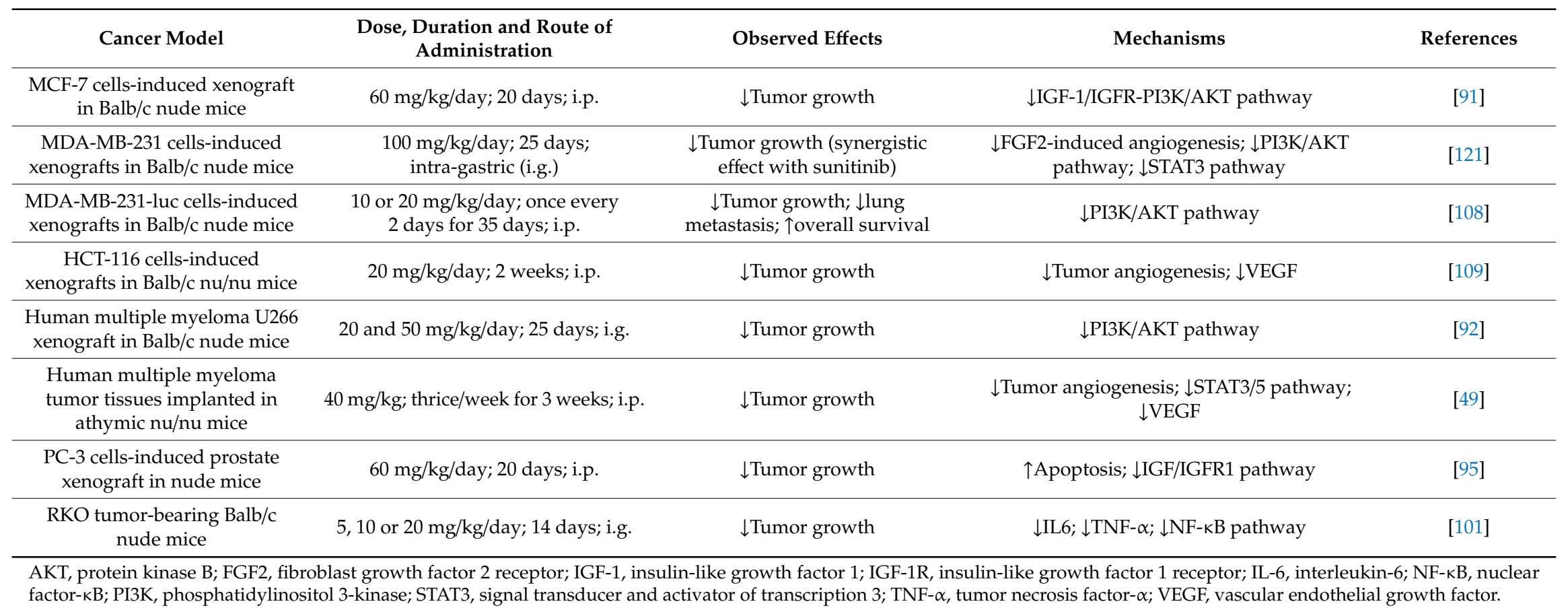


Further studies conducted to analyze the estrogenic effects of formononetin showed that it significantly elevated the expression of atrial ER subtype ER $\beta$ in ovariectomized mice [155]. Although it has not been yet demonstrated that formononetin is able to negatively impact the ER in preclinical models, this study provides us with insight that formononetin could likely affect the regulation of ERs, which are essential in the development of hormone-sensitive cancers, such as breast and ovarian cancer.

Tumor angiogenesis is a crucial process for tumor growth and metastasis for the development of cancer. The most well-established effect is the role of VEGF and VEGFR2. However, as mentioned earlier, there is evidence that the tumor can become resistant to VEGF-targeted therapy and acquire resistance against monotherapy with VEGFR inhibitors that manipulate other angiogenesis mechanisms [156]. The antiangiogenic property of formononetin is observed in nude mouse xenografts through the reduced levels of VEGF in drug-treated animals when compared against controls [109]. In preclinical models, formononetin displayed antiangiogenic properties in a myriad of cancers, especially colorectal cancer (HCT-116) [109] and breast cancer (MDA-MB-231-luc) [108]. The HCT-116 human metastatic colorectal adenocarcinoma cell line is known for its invasiveness and metastatic properties. Following treatment with formononetin, HCT-116 tumor xenografts in mice displayed a notable reduction in the number of invaded cells [109]. In another study, formononetin at doses of 25,50 or $100 \mathrm{mg} / \mathrm{kg}$ administered for 14 days significantly suppressed the growth of subcutaneously implanted osteogenic sarcoma U2OS tumor growth and was associated with the downregulation of miR-375 with concomitant upregulation of Bax, Caspase-3, and Apaf-1 [114]. Further studies in preclinical models with small molecules have been of interest in recent years as a therapeutic measure against cancer since multi-kinase inhibitors targeting VEGFR have been proven effective in clinical settings against breast tumors. However, these agents displayed signs of toxicity and did not exhibit high response rates. Formononetin derivative when administered intraperitoneally (i.p.) for 21 days $(5 \mathrm{mg} / \mathrm{kg}$ ) was shown to significantly inhibit breast tumor growth in a nude mice model when compared to EGFR inhibitors gefitinib or lapatinib and was found to be well tolerated with no significant change in the body weight of the mice [149].

Further research in the preclinical setting has found evidence that formononetin could be effective for antiangiogenesis treatment against human breast cancer (MDA-MB-231) xenografted in nude mice by preventing tumor growth via inhibition of tumor angiogenesis [121]. Furthermore, formononetin supplemented the effect of sunitinib, a receptor tyrosine kinase inhibitor that targets VEGFR2, on tumor growth inhibition through largely decreasing the invasiveness of cancer cells stimulated by tumor growth in vivo through the fibroblast growth factor receptor 2 (FGFR2)-mediated AKT signaling pathway, attenuating tumor growth and angiogenesis $[121,157]$. The inhibition of angiogenesis in xenografted human breast cancer (MDA-MB-231) by formononetin was found to modulate FGF2-induced micro-vessel growth that suppressed the emergence of rat aortic rings and angiogenesis through the repression of FGF2-initiated activation of FGFR2 and AKT signaling [121].

\section{Formononetin in Clinical Studies}

Formononetin has been tested in preclinical settings for other diseases, such as Alzheimer's [158], but clinical studies for the use of formononetin as a treatment method for cancer have yet to be conducted. Jarred and colleagues [159] identified that treatment with a red clover-derived isoflavone mixture was able to induce apoptosis in low- to moderate-grade human prostate carcinoma. Further clinical research needs to be performed to ascertain the anti-cancer properties of formononetin in multiple cancer types.

\section{Conclusion and Future Perspectives}

Evidence presented in this review provides a comprehensive summary on the potential anticancer properties of formononetin in both in vitro and in vivo studies and the current progress of clinical studies. Numerous molecular targets and mechanisms of actions are involved in the antitumorigenic property (primarily on the induction of cell apoptosis and the inhibition of cell proliferation) of formononetin as evidenced from numerous in vitro studies, whereas the safety and efficacy of formononetin and its 
metabolites in biological systems are further confirmed in in vivo studies. The tumor-inhibitory effects of formononetin have been associated with the modulation of PI3K/AKT and STAT3 signaling pathways in both in vitro and in vivo models. The various anticancer molecular targets of formononetin are briefly summarized in Figure 3. In addition, formononetin has been found to possess additive and synergistic effects with chemotherapeutic drugs, such as Sunitinib. The potential role for formononetin to be used as an adjunct therapy and future prospective drug development for cancer patients are supported through these findings. However, further studies need to be conducted (both in vivo and clinical studies) to allow for further assessment of the efficacy and safety of formononetin for prevention and treatment of various cancer types. This is crucial as various formononetin derivatives and metabolites have varying pharmacokinetic properties and activities that need to be fully elucidated, and this requires further investigation to ensure that this bioactive phytochemical is safe for clinical development. The significant antitumor properties of formononetin make it a novel candidate for anticancer drug development.

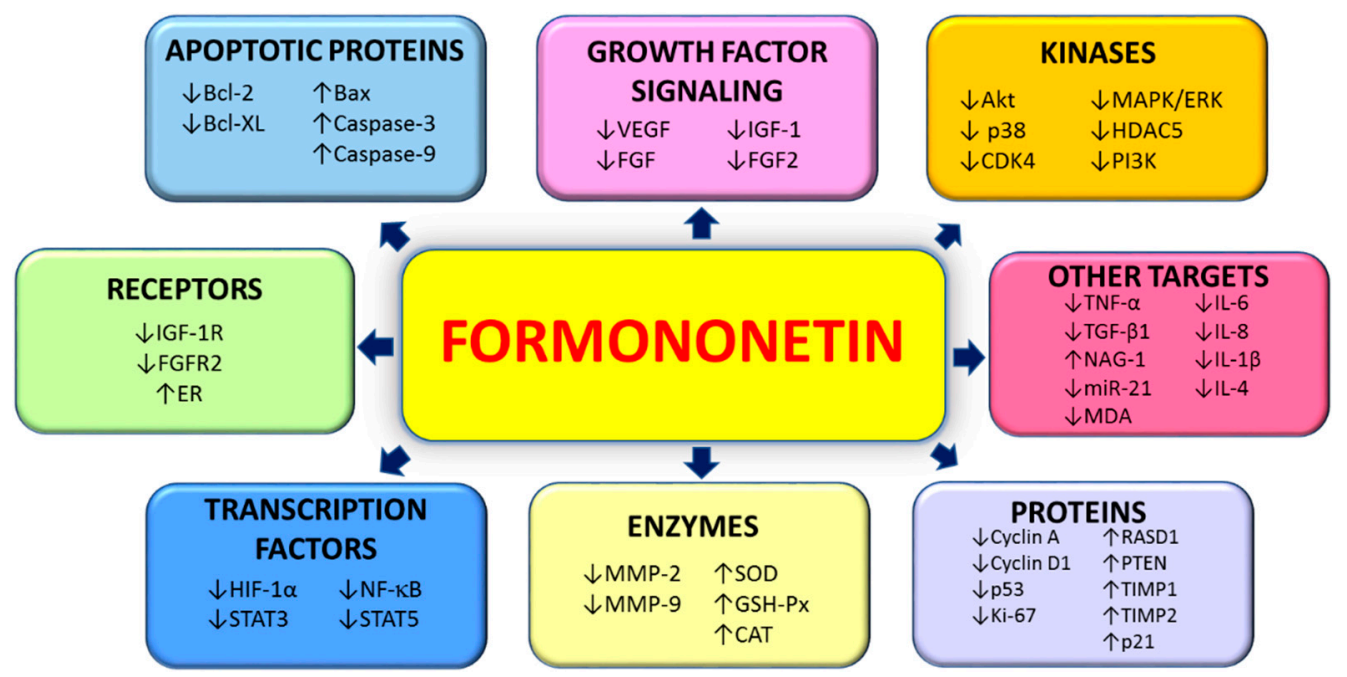

Figure 3. Molecular targets influenced by formononetin in cancer.

Author Contributions: Conceptualization, S.K.L.O., M.K.S., L.F., K.S.A., G.S. and A.B.; writing-original draft preparation, S.K.L.O., L.F. and M.K.S.; writing-review and editing, G.S., K.S.A., S.E.F., F.A. and A.B.; funding acquisition, G.S. and K.S.A.

Funding: This work was supported by grants from National Research Foundation (NRF)-Korean government awarded to K.S.A (NRF-2015R1A4A1042399, 2017R1A6A3A11031224 and 2018R1D1A1B07042969).

Conflicts of Interest: The authors declare that they have no competing interests.

\section{Abbreviations}

AKT

protein kinase B

AP-1 activator protein 1

Bax Bcl-2-associated protein

Bcl-2 B-cell lymphoma 2

Bcl-xL B-cell lymphoma-extra-large

b-FGF basic fibroblast growth factor

CAT catalase

CDK cyclin-dependent kinase

CD4 cluster of differentiation 4

CREB CAMP response element-binding protein

DMSO dimethyl sulfoxide

EGR3 early growth response protein 3 


$\begin{array}{ll}\text { EMT } & \text { epithelial-mesenchymal transition } \\ \text { ERK } & \text { extracellular signal regulated kinase } \\ \text { FGF } & \text { fibroblast growth factor } \\ \text { FGF2 } & \text { fibroblast growth factor 2 receptor } \\ \text { GSH-Px } & \text { glutathione peroxidase } \\ \text { GSK-3 } \beta & \text { glycogen synthase kinase } 3 \beta \\ \text { HDAC5 } & \text { histone deacetylase } 5 \\ \text { HIF-1 } \alpha & \text { hypoxia-inducible factor } 1 \alpha \\ \text { IGF-1 } & \text { insulin-like growth factor 1 } \\ \text { IGF-1R } & \text { insulin-like growth factor 1 receptor } \\ \text { IL-1 } \beta & \text { interleukin 1 } \beta \\ \text { IL-4 } & \text { interleukin-4 } \\ \text { IL-6 } & \text { interleukin-6 } \\ \text { IL-8 } & \text { interleukin-8 } \\ \text { MAPK } & \text { mitogen-activated protein kinase } \\ \text { MDA } & \text { malondialdehyde } \\ \text { miR-21 } & \text { microRNA 21 } \\ \text { MMP } & \text { matrix metalloproteinase } \\ \text { NAG-1 } & \text { NSAID-activated gene } \\ \text { NF- } \text { B } & \text { nuclear factor- } \text { B B } \\ \text { PI3K } & \text { phosphatidylinositol 3-kinase } \\ \text { PTEN } & \text { phosphatase and tensin homolog } \\ \text { ROCK } & \text { Rho-associated protein kinase } \\ \text { siRNA } & \text { small interfering ribonucleic acid } \\ \text { SOD } & \text { superoxide dismutase } \\ \text { STAT3 } & \text { signal transducer and activator of transcription 3 } \\ \text { Sul-F } & \text { formononetin-3'-sulphonate } \\ \text { TMZ } & \text { temozolomide } \\ \text { TNF- } \alpha & \text { tumor necrosis factor- } \alpha \\ \text { VCAM-1 } & \text { vascular cell adhesion protein 1 } \\ \text { VEGF } & \text { vascular endothelial growth factor } \\ \text { VEGFR } & \text { vascular endothelial growth factor receptor } \\ \text { Wnt } & \text { Wingless } \\ & \end{array}$

\section{References}

1. Martin, T.A.; Ye, L.; Sanders, A.J.; Lane, J.; WG, J. Cancer invasion and metastasis: Molecular and cellular perspective. In Metastatic Cancer Clinical Biological Perspectives; Landes Bioscience 2000-2013: Austin, TX, USA, 2013. [CrossRef]

2. Cooper, G.M. The development and causes of cancer. In The Cell: A Molecular Approach, 2nd ed.; Sinauer Associates: Sunderland, MA, USA, 2000.

3. Ferlay, J.; Colombet, M.; Soerjomataram, I.; Mathers, C.; Parkin, D.M.; Pineros, M.; Znaor, A.; Bray, F. Estimating the global cancer incidence and mortality in 2018: Globocan sources and methods. Int. J. Cancer 2018. [CrossRef]

4. Bray, F.; Ferlay, J.; Soerjomataram, I.; Siegel, R.L.; Torre, L.A.; Jemal, A. Global cancer statistics 2018: Globocan estimates of incidence and mortality worldwide for 36 cancers in 185 countries. CA Cancer J. Clin. 2018, 68, 394-424. [CrossRef]

5. Shanmugam, M.K.; Kannaiyan, R.; Sethi, G. Targeting cell signaling and apoptotic pathways by dietary agents: Role in the prevention and treatment of cancer. Nutr. Cancer 2011, 63, 161-173. [CrossRef] [PubMed]

6. Clarke, G.; Johnston, S.; Corrie, P.; Kuhn, I.; Barclay, S. Withdrawal of anticancer therapy in advanced disease: A systematic literature review. BMC Cancer 2015, 15, 892. [CrossRef] [PubMed]

7. Onakpoya, I.J.; Heneghan, C.J.; Aronson, J.K. Post-marketing withdrawal of 462 medicinal products because of adverse drug reactions: A systematic review of the world literature. BMC Med. 2016, 14, 10. [CrossRef] [PubMed] 
8. Pan, H.; Gray, R.; Braybrooke, J.; Davies, C.; Taylor, C.; McGale, P.; Peto, R.; Pritchard, K.I.; Bergh, J.; Dowsett, M.; et al. 20-year risks of breast-cancer recurrence after stopping endocrine therapy at 5 years. N. Engl. J. Med. 2017, 377, 1836-1846. [CrossRef] [PubMed]

9. Demain, A.L.; Vaishnav, P. Natural products for cancer chemotherapy. Microb. Biotechnol. 2011, 4, 687-699. [CrossRef]

10. Neill, U.S. From branch to bedside: Youyou tu is awarded the 2011 lasker debakey clinical medical research award for discovering artemisinin as a treatment for malaria. J. Clin. Investig. 2011, 121, 3768-3773. [CrossRef]

11. Bishayee, A.; Sethi, G. Bioactive natural products in cancer prevention and therapy: Progress and promise. Semin. Cancer Biol. 2016, 40-41, 1-3. [CrossRef]

12. Newman, D.J.; Cragg, G.M. Natural products as sources of new drugs over the 30 years from 1981 to 2010. J. Nat. Prod. 2012, 75, 311-335. [CrossRef]

13. Cragg, G.M.; Pezzuto, J.M. Natural products as a vital source for the discovery of cancer chemotherapeutic and chemopreventive agents. Med. Princ. Pract. 2016, 25, 41-59. [CrossRef] [PubMed]

14. Deorukhkar, A.; Krishnan, S.; Sethi, G.; Aggarwal, B.B. Back to basics: How natural products can provide the basis for new therapeutics. Exp. Opin. Invest. Drugs 2007, 16, 1753-1773. [CrossRef] [PubMed]

15. Yang, S.F.; Weng, C.J.; Sethi, G.; Hu, D.N. Natural bioactives and phytochemicals serve in cancer treatment and prevention. Evid. Based Complement Altern. Med. 2013, 2013, 698190. [CrossRef] [PubMed]

16. Tang, C.H.; Sethi, G.; Kuo, P.L. Novel medicines and strategies in cancer treatment and prevention. BioMed. Res. Int. 2014, 2014, 474078. [CrossRef] [PubMed]

17. Hsieh, Y.S.; Yang, S.F.; Sethi, G.; Hu, D.N. Natural bioactives in cancer treatment and prevention. BioMed. Res. Int. 2015, 2015, 182835. [CrossRef]

18. Yarla, N.S.; Bishayee, A.; Sethi, G.; Reddanna, P.; Kalle, A.M.; Dhananjaya, B.L.; Dowluru, K.S.; Chintala, R.; Duddukuri, G.R. Targeting arachidonic acid pathway by natural products for cancer prevention and therapy. Semin. Cancer Biol. 2016, 40-41, 48-81. [CrossRef]

19. Hasanpourghadi, M.; Looi, C.Y.; Pandurangan, A.K.; Sethi, G.; Wong, W.F.; Mustafa, M.R. Phytometabolites targeting the warburg effect in cancer cells: A mechanistic review. Curr. Drug Targets 2017, 18, 1086-1094. [CrossRef]

20. Shanmugam, M.K.; Warrier, S.; Kumar, A.P.; Sethi, G.; Arfuso, F. Potential role of natural compounds as anti-angiogenic agents in cancer. Curr. Vasc. Pharmacol. 2017, 15, 503-519. [CrossRef]

21. Aggarwal, B.B.; Sethi, G.; Baladandayuthapani, V.; Krishnan, S.; Shishodia, S. Targeting cell signaling pathways for drug discovery: An old lock needs a new key. J. Cell Biochem. 2007, 102, 580-592. [CrossRef]

22. Jung, Y.Y.; Hwang, S.T.; Sethi, G.; Fan, L.; Arfuso, F.; Ahn, K.S. Potential anti-inflammatory and anti-cancer properties of farnesol. Molecules 2018, 23, 2827. [CrossRef]

23. Merarchi, M.; Sethi, G.; Fan, L.; Mishra, S.; Arfuso, F.; Ahn, K.S. Molecular targets modulated by fangchinoline in tumor cells and preclinical models. Molecules 2018, 23, 2538. [CrossRef] [PubMed]

24. Sethi, G.; Shanmugam, M.K.; Warrier, S.; Merarchi, M.; Arfuso, F.; Kumar, A.P.; Bishayee, A. Pro-apoptotic and anti-cancer properties of diosgenin: A comprehensive and critical review. Nutrients 2018, 10, 645. [CrossRef] [PubMed]

25. Ko, J.H.; Sethi, G.; Um, J.Y.; Shanmugam, M.K.; Arfuso, F.; Kumar, A.P.; Bishayee, A.; Ahn, K.S. The role of resveratrol in cancer therapy. Int. J. Mol. Sci. 2017, 18, 2589. [CrossRef] [PubMed]

26. Tewari, D.; Nabavi, S.F.; Nabavi, S.M.; Sureda, A.; Farooqi, A.A.; Atanasov, A.G.; Vacca, R.A.; Sethi, G.; Bishayee, A. Targeting activator protein 1 signaling pathway by bioactive natural agents: Possible therapeutic strategy for cancer prevention and intervention. Pharmacol. Res. 2018, 128, 366-375. [CrossRef] [PubMed]

27. Shanmugam, M.K.; Lee, J.H.; Chai, E.Z.; Kanchi, M.M.; Kar, S.; Arfuso, F.; Dharmarajan, A.; Kumar, A.P.; Ramar, P.S.; Looi, C.Y.; et al. Cancer prevention and therapy through the modulation of transcription factors by bioactive natural compounds. Semin. Cancer Biol. 2016, 40-41, 35-47. [CrossRef] [PubMed]

28. Shanmugam, M.K.; Nguyen, A.H.; Kumar, A.P.; Tan, B.K.; Sethi, G. Targeted inhibition of tumor proliferation, survival, and metastasis by pentacyclic triterpenoids: Potential role in prevention and therapy of cancer. Cancer Lett. 2012, 320, 158-170. [CrossRef] [PubMed]

29. Shrimali, D.; Shanmugam, M.K.; Kumar, A.P.; Zhang, J.; Tan, B.K.; Ahn, K.S.; Sethi, G. Targeted abrogation of diverse signal transduction cascades by emodin for the treatment of inflammatory disorders and cancer. Cancer Lett. 2013, 341, 139-149. [CrossRef] 
30. Ranaware, A.M.; Banik, K.; Deshpande, V.; Padmavathi, G.; Roy, N.K.; Sethi, G.; Fan, L.; Kumar, A.P.; Kunnumakkara, A.B. Magnolol: A neolignan from the magnolia family for the prevention and treatment of cancer. Int. J. Mol. Sci. 2018, 19, 2362. [CrossRef]

31. Ko, J.H.; Arfuso, F.; Sethi, G.; Ahn, K.S. Pharmacological utilization of bergamottin, derived from grapefruits, in cancer prevention and therapy. Int. J. Mol. Sci. 2018, 19, 4048. [CrossRef]

32. Parikh, N.R.; Mandal, A.; Bhatia, D.; Siveen, K.S.; Sethi, G.; Bishayee, A. Oleanane triterpenoids in the prevention and therapy of breast cancer: Current evidence and future perspectives. Phytochem. Rev. 2014, 13, 793-810. [CrossRef]

33. Shanmugam, M.K.; Dai, X.; Kumar, A.P.; Tan, B.K.; Sethi, G.; Bishayee, A. Oleanolic acid and its synthetic derivatives for the prevention and therapy of cancer: Preclinical and clinical evidence. Cancer Lett. 2014, 346, 206-216. [CrossRef] [PubMed]

34. Rajendran, P.; Li, F.; Shanmugam, M.K.; Kannaiyan, R.; Goh, J.N.; Wong, K.F.; Wang, W.; Khin, E.; Tergaonkar, V.; Kumar, A.P.; et al. Celastrol suppresses growth and induces apoptosis of human hepatocellular carcinoma through the modulation of stat3/jak2 signaling cascade in vitro and in vivo. Cancer Prev. Res. (Phila.) 2012, 5, 631-643. [CrossRef] [PubMed]

35. Kannaiyan, R.; Hay, H.S.; Rajendran, P.; Li, F.; Shanmugam, M.K.; Vali, S.; Abbasi, T.; Kapoor, S.; Sharma, A.; Kumar, A.P.; et al. Celastrol inhibits proliferation and induces chemosensitization through down-regulation of nf-kappab and stat3 regulated gene products in multiple myeloma cells. Br. J. Pharmacol. 2011, 164, 1506-1521. [CrossRef] [PubMed]

36. Akincilar, S.C.; Low, K.C.; Liu, C.Y.; Yan, T.D.; Oji, A.; Ikawa, M.; Li, S.; Tergaonkar, V. Quantitative assessment of telomerase components in cancer cell lines. FEBS Lett. 2015, 589, 974-984. [CrossRef]

37. Auyeung, K.K.; Ko, J.K. Novel herbal flavonoids promote apoptosis but differentially induce cell cycle arrest in human colon cancer cell. Invest. New Drugs 2010, 28, 1-13. [CrossRef]

38. Sethi, G.; Shanmugam, M.K.; Ramachandran, L.; Kumar, A.P.; Tergaonkar, V. Multifaceted link between cancer and inflammation. Biosci. Rep. 2012, 32, 1-15. [CrossRef] [PubMed]

39. Liu, D.; Miao, H.; Zhao, Y.; Kang, X.; Shang, S.; Xiang, W.; Shi, R.; Hou, A.; Wang, R.; Zhao, K.; et al. NF-kB potentiates tumor growth by suppressing a novel target lpts. Cell Commun. Signal. 2017, 15, 39. [CrossRef] [PubMed]

40. Arora, L.; Kumar, A.P.; Arfuso, F.; Chng, W.J.; Sethi, G. The role of signal transducer and activator of transcription 3 (STAT3) and its targeted inhibition in hematological malignancies. Cancers 2018, 10. [CrossRef]

41. Lee, J.H.; Kim, C.; Lee, S.G.; Sethi, G.; Ahn, K.S. Ophiopogonin d, a steroidal glycoside abrogates STAT3 signaling cascade and exhibits anti-cancer activity by causing GSH/GSSG imbalance in lung carcinoma. Cancers 2018, 10. [CrossRef]

42. Wong, A.L.A.; Hirpara, J.L.; Pervaiz, S.; Eu, J.Q.; Sethi, G.; Goh, B.C. Do stat3 inhibitors have potential in the future for cancer therapy? Expert Opin. Investig. Drugs 2017, 26, 883-887. [CrossRef]

43. Lee, J.H.; Kim, C.; Baek, S.H.; Ko, J.H.; Lee, S.G.; Yang, W.M.; Um, J.Y.; Sethi, G.; Ahn, K.S. Capsazepine inhibits jak/stat3 signaling, tumor growth, and cell survival in prostate cancer. Oncotarget 2017, 8, 17700-17711. [CrossRef]

44. Zhang, J.; Ahn, K.S.; Kim, C.; Shanmugam, M.K.; Siveen, K.S.; Arfuso, F.; Samym, R.P.; Deivasigamanim, A.; Lim, L.H.; Wang, L.; et al. Nimbolide-induced oxidative stress abrogates stat3 signaling cascade and inhibits tumor growth in transgenic adenocarcinoma of mouse prostate model. Antioxid. Redox Signal. 2016, 24, 575-589. [CrossRef] [PubMed]

45. Chai, E.Z.; Shanmugam, M.K.; Arfuso, F.; Dharmarajan, A.; Wang, C.; Kumar, A.P.; Samy, R.P.; Lim, L.H.; Wang, L.; Goh, B.C.; et al. Targeting transcription factor stat3 for cancer prevention and therapy. Pharmacol. Ther. 2016, 162, 86-97. [CrossRef] [PubMed]

46. Subramaniam, A.; Shanmugam, M.K.; Ong, T.H.; Li, F.; Perumal, E.; Chen, L.; Vali, S.; Abbasi, T.; Kapoor, S.; Ahn, K.S.; et al. Emodin inhibits growth and induces apoptosis in an orthotopic hepatocellular carcinoma model by blocking activation of stat3. Br. J. Pharmacol. 2013, 170, 807-821. [CrossRef] [PubMed]

47. Subramaniam, A.; Shanmugam, M.K.; Perumal, E.; Li, F.; Nachiyappan, A.; Dai, X.; Swamy, S.N.; Ahn, K.S.; Kumar, A.P.; Tan, B.K.; et al. Potential role of signal transducer and activator of transcription (stat)3 signaling pathway in inflammation, survival, proliferation and invasion of hepatocellular carcinoma. Biochim. Biophys. Acta 2013, 1835, 46-60. [CrossRef] [PubMed] 
48. Jung, Y.Y.; Lee, J.H.; Nam, D.; Narula, A.S.; Namjoshi, O.A.; Blough, B.E.; Um, J.Y.; Sethi, G.; Ahn, K.S. Anti-myeloma effects of icariin are mediated through the attenuation of jak/stat3-dependent signaling cascade. Front. Pharmacol. 2018, 9, 531. [CrossRef]

49. Kim, C.; Lee, S.G.; Yang, W.M.; Arfuso, F.; Um, J.Y.; Kumar, A.P.; Bian, J.; Sethi, G.; Ahn, K.S. Formononetin-induced oxidative stress abrogates the activation of stat $3 / 5$ signaling axis and suppresses the tumor growth in multiple myeloma preclinical model. Cancer Lett. 2018, 431, 123-141. [CrossRef]

50. Li, F.; Zhang, J.; Arfuso, F.; Chinnathambi, A.; Zayed, M.E.; Alharbi, S.A.; Kumar, A.P.; Ahn, K.S.; Sethi, G. Nf-kappab in cancer therapy. Arch. Toxicol. 2015, 89, 711-731. [CrossRef]

51. Manu, K.A.; Shanmugam, M.K.; Ramachandran, L.; Li, F.; Fong, C.W.; Kumar, A.P.; Tan, P.; Sethi, G. First evidence that gamma-tocotrienol inhibits the growth of human gastric cancer and chemosensitizes it to capecitabine in a xenograft mouse model through the modulation of nf-kappab pathway. Clin. Cancer Res. 2012, 18, 2220-2229. [CrossRef]

52. Shanmugam, M.K.; Ahn, K.S.; Lee, J.H.; Kannaiyan, R.; Mustafa, N.; Manu, K.A.; Siveen, K.S.; Sethi, G.; Chng, W.J.; Kumar, A.P. Celastrol attenuates the invasion and migration and augments the anticancer effects of bortezomib in a xenograft mouse model of multiple myeloma. Front. Pharmacol. 2018, 9, 365. [CrossRef]

53. Manu, K.A.; Shanmugam, M.K.; Ramachandran, L.; Li, F.; Siveen, K.S.; Chinnathambi, A.; Zayed, M.E.; Alharbi, S.A.; Arfuso, F.; Kumar, A.P.; et al. Isorhamnetin augments the anti-tumor effect of capeciatbine through the negative regulation of nf-kappab signaling cascade in gastric cancer. Cancer Lett. 2015, 363, 28-36. [CrossRef] [PubMed]

54. Li, F.; Shanmugam, M.K.; Siveen, K.S.; Wang, F.; Ong, T.H.; Loo, S.Y.; Swamy, M.M.; Mandal, S.; Kumar, A.P.; Goh, B.C.; et al. Garcinol sensitizes human head and neck carcinoma to cisplatin in a xenograft mouse model despite downregulation of proliferative biomarkers. Oncotarget 2015, 6, 5147-5163. [CrossRef] [PubMed]

55. Mohan, C.D.; Bharathkumar, H.; Dukanya; Rangappa, S.; Shanmugam, M.K.; Chinnathambi, A.; Alharbi, S.A.; Alahmadi, T.A.; Bhattacharjee, A.; Lobie, P.E.; et al. N-substituted pyrido-1,4-oxazin-3-ones induce apoptosis of hepatocellular carcinoma cells by targeting nf-kappab signaling pathway. Front. Pharmacol. 2018, 9, 1125. [PubMed]

56. Raghunath, A.; Sundarraj, K.; Arfuso, F.; Sethi, G.; Perumal, E. Dysregulation of NRF2 in hepatocellular carcinoma: Role in cancer progression and chemoresistance. Cancers 2018, 10. [CrossRef] [PubMed]

57. Lee, J.H.; Kim, C.; Ko, J.H.; Jung, Y.Y.; Jung, S.H.; Kim, E.; Kong, M.; Chinnathambi, A.; Alahmadi, T.A.; Alharbi, S.A.; et al. Casticin inhibits growth and enhances ionizing radiation-induced apoptosis through the suppression of stat3 signaling cascade. J. Cell Biochem. 2019, 120, 9787-9798. [CrossRef] [PubMed]

58. Shanmugam, M.K.; Ahn, K.S.; Hsu, A.; Woo, C.C.; Yuan, Y.; Tan, K.H.B.; Chinnathambi, A.; Alahmadi, T.A.; Alharbi, S.A.; Koh, A.P.F.; et al. Thymoquinone inhibits bone metastasis of breast cancer cells through abrogation of the cxcr4 signaling axis. Front. Pharmacol. 2018, 9, 1294. [CrossRef]

59. Liu, L.; Ahn, K.S.; Shanmugam, M.K.; Wang, H.; Shen, H.; Arfuso, F.; Chinnathambi, A.; Alharbi, S.A.; Chang, Y.; Sethi, G.; et al. Oleuropein induces apoptosis via abrogating nf-kappab activation cascade in estrogen receptor-negative breast cancer cells. J. Cell Biochem. 2019, 120, 4504-4513. [CrossRef]

60. Li, F.; Sethi, G. Targeting transcription factor nf-kappab to overcome chemoresistance and radioresistance in cancer therapy. Biochim. Biophys. Acta 2010, 1805, 167-180.

61. Sethi, G.; Tergaonkar, V. Potential pharmacological control of the nf-kappab pathway. Trends. Pharmacol. Sci. 2009, 30, 313-321. [CrossRef]

62. Ahn, K.S.; Sethi, G.; Aggarwal, B.B. Nuclear factor-kappa b: From clone to clinic. Curr. Mol. Med. 2007, 7, 619-637. [CrossRef]

63. Puar, Y.R.; Shanmugam, M.K.; Fan, L.; Arfuso, F.; Sethi, G.; Tergaonkar, V. Evidence for the involvement of the master transcription factor nf-kappab in cancer initiation and progression. Biomedicines 2018, 6. [CrossRef]

64. Chai, E.Z.; Siveen, K.S.; Shanmugam, M.K.; Arfuso, F.; Sethi, G. Analysis of the intricate relationship between chronic inflammation and cancer. Biochem. J. 2015, 468, 1-15. [CrossRef] [PubMed]

65. Loh, C.Y.; Arya, A.; Naema, A.F.; Wong, W.F.; Sethi, G.; Looi, C.Y. Signal transducer and activator of transcription (stats) proteins in cancer and inflammation: Functions and therapeutic implication. Front. Oncol. 2019, 9, 48. [CrossRef] [PubMed]

66. Lee, M.; Hirpara, J.L.; Eu, J.Q.; Sethi, G.; Wang, L.; Goh, B.C.; Wong, A.L. Targeting stat3 and oxidative phosphorylation in oncogene-addicted tumors. Redox Biol. 2018, 101073. [CrossRef] [PubMed] 
67. Liu, Y.; Tergaonkar, V.; Krishna, S.; Androphy, E.J. Human papillomavirus type 16 e6-enhanced susceptibility of 1929 cells to tumor necrosis factor alpha correlates with increased accumulation of reactive oxygen species. J. Biol. Chem. 1999, 274, 24819-24827. [CrossRef]

68. Akincilar, S.C.; Khattar, E.; Boon, P.L.; Unal, B.; Fullwood, M.J.; Tergaonkar, V. Long-range chromatin interactions drive mutant tert promoter activation. Cancer Discov. 2016, 6, 1276-1291. [CrossRef]

69. Khattar, E.; Kumar, P.; Liu, C.Y.; Akincilar, S.C.; Raju, A.; Lakshmanan, M.; Maury, J.J.; Qiang, Y.; Li, S.; Tan, E.Y.; et al. Telomerase reverse transcriptase promotes cancer cell proliferation by augmenting trna expression. J. Clin. Investig. 2016, 126, 4045-4060. [CrossRef]

70. Mishra, S.; Verma, S.S.; Rai, V.; Awasthee, N.; Chava, S.; Hui, K.M.; Kumar, A.P.; Challagundla, K.B.; Sethi, G.; Gupta, S.C. Long non-coding rnas are emerging targets of phytochemicals for cancer and other chronic diseases. Cell Mol. Life Sci. 2019, 76, 1947-1966. [CrossRef]

71. Deng, S.; Shanmugam, M.K.; Kumar, A.P.; Yap, C.T.; Sethi, G.; Bishayee, A. Targeting autophagy using natural compounds for cancer prevention and therapy. Cancer 2019, 125, 1228-1246. [CrossRef]

72. Siveen, K.S.; Sikka, S.; Surana, R.; Dai, X.; Zhang, J.; Kumar, A.P.; Tan, B.K.; Sethi, G.; Bishayee, A. Targeting the stat3 signaling pathway in cancer: Role of synthetic and natural inhibitors. Biochim. Biophys. Acta 2014, 1845, 136-154. [CrossRef]

73. Yang, M.H.; Jung, S.H.; Sethi, G.; Ahn, K.S. Pleiotropic pharmacological actions of capsazepine, a synthetic analogue of capsaicin, against various cancers and inflammatory diseases. Molecules 2019, 24, 995. [CrossRef] [PubMed]

74. Girisa, S.; Shabnam, B.; Monisha, J.; Fan, L.; Halim, C.E.; Arfuso, F.; Ahn, K.S.; Sethi, G.; Kunnumakkara, A.B. Potential of zerumbone as an anti-cancer agent. Molecules 2019, 24, 734. [CrossRef] [PubMed]

75. Lee, J.H.; Kim, C.; Um, J.Y.; Sethi, G.; Ahn, K.S. Casticin-induced inhibition of cell growth and survival are mediated through the dual modulation of akt/mtor signaling cascade. Cancers 2019, 11, 254. [CrossRef] [PubMed]

76. Aggarwal, V.; Kashyap, D.; Sak, K.; Tuli, H.S.; Jain, A.; Chaudhary, A.; Garg, V.K.; Sethi, G.; Yerer, M.B. Molecular mechanisms of action of tocotrienols in cancer: Recent trends and advancements. Int. J. Mol. Sci. 2019, 20, 656. [CrossRef] [PubMed]

77. Polak, R.; Phillips, E.M.; Campbell, A. Legumes: Health benefits and culinary approaches to increase intake. Clin. Diabetes 2015, 33, 198-205. [CrossRef] [PubMed]

78. Cassileth, B. Complementary therapies, herbs, and other otc agents: Red clover (trifolium pratense). Oncology (Williston Park) 2010, 24, 960. [PubMed]

79. Kaczmarczyk-Sedlak, I.; Wojnar, W.; Zych, M.; Ozimina-Kaminska, E.; Taranowicz, J.; Siwek, A. Effect of formononetin on mechanical properties and chemical composition of bones in rats with ovariectomy-induced osteoporosis. Evid. Based Complement. Altern. Med. 2013, 2013, 457052. [CrossRef]

80. Patisaul, H.B.; Jefferson, W. The pros and cons of phytoestrogens. Front Neuroendocrinol. 2010, 31, 400-419. [CrossRef] [PubMed]

81. Lukaczer, D.; Darland, G.; Tripp, M.; Liska, D.; Lerman, R.H.; Schiltz, B.; Bland, J.S. Clinical effects of a proprietary combination isoflavone nutritional supplement in menopausal women: A pilot trial. Altern. Ther. Health Med. 2005, 11, 60-65.

82. Hidalgo, L.A.; Chedraui, P.A.; Morocho, N.; Ross, S.; San Miguel, G. The effect of red clover isoflavones on menopausal symptoms, lipids and vaginal cytology in menopausal women: A randomized, double-blind, placebo-controlled study. Gynecol. Endocrinol. 2005, 21, 257-264. [CrossRef]

83. Atkinson, C.; Compston, J.E.; Day, N.E.; Dowsett, M.; Bingham, S.A. The effects of phytoestrogen isoflavones on bone density in women: A double-blind, randomized, placebo-controlled trial. Am. J. Clin. Nutr. 2004, 79, 326-333. [CrossRef]

84. Nestel, P.J.; Pomeroy, S.; Kay, S.; Komesaroff, P.; Behrsing, J.; Cameron, J.D.; West, L. Isoflavones from red clover improve systemic arterial compliance but not plasma lipids in menopausal women. J. Clin. Endocrinol. Metab. 1999, 84, 895-898. [CrossRef]

85. Wang, A.L.; Li, Y.; Zhao, Q.; Fan, L.Q. Formononetin inhibits colon carcinoma cell growth and invasion by microrna149mediated ephb3 downregulation and inhibition of pi3k/akt and stat3 signaling pathways. Mol. Med. Rep. 2018, 17, 7721-7729. [PubMed] 
86. Zhang, S.; Tang, X.; Tian, J.; Li, C.; Zhang, G.; Jiang, W.; Zhang, Z. Cardioprotective effect of sulphonated formononetin on acute myocardial infarction in rats. Basic Clin. Pharmacol. Toxicol. 2011, 108, 390-395. [CrossRef] [PubMed]

87. Zhu, H.; Zou, L.; Tian, J.; Lin, F.; He, J.; Hou, J. Protective effects of sulphonated formononetin in a rat model of cerebral ischemia and reperfusion injury. Planta Med. 2014, 80, 262-268. [CrossRef] [PubMed]

88. Tolleson, W.H.; Doerge, D.R.; Churchwell, M.I.; Marques, M.M.; Roberts, D.W. Metabolism of biochanin a and formononetin by human liver microsomes in vitro. J. Agric. Food Chem. 2002, 50, 4783-4790. [CrossRef] [PubMed]

89. Park, J.; Kim, S.H.; Cho, D.; Kim, T.S. Formononetin, a phyto-oestrogen, and its metabolites up-regulate interleukin-4 production in activated t cells via increased ap-1 DNA binding activity. Immunology 2005, 116, 71-81. [CrossRef] [PubMed]

90. Liu, Y.; He, J.; Chen, X.; Li, J.; Shen, M.; Yu, W.; Yang, Y.; Xiao, Z. The proapoptotic effect of formononetin in human osteosarcoma cells: Involvement of inactivation of erk and akt pathways. Cell Physiol. Biochem. 2014, 34, 637-645. [CrossRef] [PubMed]

91. Chen, J.; Zeng, J.; Xin, M.; Huang, W.; Chen, X. Formononetin induces cell cycle arrest of human breast cancer cells via igf1/pi3k/akt pathways in vitro and in vivo. Horm. Metab. Res. 2011, 43, 681-686. [CrossRef] [PubMed]

92. Chen, J.; Sun, L. Formononetin-induced apoptosis by activation of ras/p38 mitogen-activated protein kinase in estrogen receptor-positive human breast cancer cells. Horm. Metab. Res. 2012, 44, 943-948. [CrossRef]

93. Chen, J.; Zhao, X.; Ye, Y.; Wang, Y.; Tian, J. Estrogen receptor beta-mediated proliferative inhibition and apoptosis in human breast cancer by calycosin and formononetin. Cell Physiol. Biochem. 2013, 32, 1790-1797. [CrossRef]

94. Ye, Y.; Hou, R.; Chen, J.; Mo, L.; Zhang, J.; Huang, Y.; Mo, Z. Formononetin-induced apoptosis of human prostate cancer cells through erk1/2 mitogen-activated protein kinase inactivation. Horm. Metab. Res. 2012, 44, 263-267. [CrossRef]

95. Li, T.; Zhao, X.; Mo, Z.; Huang, W.; Yan, H.; Ling, Z.; Ye, Y. Formononetin promotes cell cycle arrest via downregulation of akt/cyclin d1/cdk4 in human prostate cancer cells. Cell Physiol. Biochem. 2014, 34, 1351-1358. [CrossRef] [PubMed]

96. Yang, Y.; Zhao, Y.; Ai, X.; Cheng, B.; Lu, S. Formononetin suppresses the proliferation of human non-small cell lung cancer through induction of cell cycle arrest and apoptosis. Int. J. Clin. Exp. Pathol. 2014, 7, 8453-8461.

97. Jin, Y.M.; Xu, T.M.; Zhao, Y.H.; Wang, Y.C.; Cui, M.H. In vitro and in vivo anti-cancer activity of formononetin on human cervical cancer cell line HELA. Tumour Biol. 2014, 35, 2279-2284. [CrossRef]

98. Wu, Y.; Zhang, X.; Li, Z.; Yan, H.; Qin, J.; Li, T. Formononetin inhibits human bladder cancer cell proliferation and invasiveness via regulation of mir-21 and pten. Food Funct. 2017, 8, 1061-1066. [CrossRef]

99. Park, S.; Bazer, F.W.; Lim, W.; Song, G. The o-methylated isoflavone, formononetin, inhibits human ovarian cancer cell proliferation by sub g0/g1 cell phase arrest through PI3K/AKT and ERK1/2 inactivation. J. Cell Biochem. 2018, 119, 7377-7387. [CrossRef] [PubMed]

100. Wu, X.L.; Li, H.Y.; Wang, R.H.; Ma, X.X.; Yue, B.; Yan, J.; Yang, N.L.; Xing, X.H.; Sheng, Z.F.; Wang, G.H.; et al. Formononetin suppresses hypoxia inducible factor- $1 \alpha /$ inflammatory cytokines expression via inhibiting akt signal pathway in multiple myeloma cells. Int. J. Clin. Exp. Med. 2016, 9, 1117-1127.

101. Huang, J.; Xie, M.; Gao, P.; Ye, Y.; Liu, Y.; Zhao, Y.; Luo, W.; Ling, Z.; Cao, Y.; Zhang, S.; et al. Antiproliferative effects of formononetin on human colorectal cancer via suppressing cell growth in vitro and in vivo. Proc. Biochem. 2015, 50, 912-917. [CrossRef]

102. Fouad, Y.A.; Aanei, C. Revisiting the hallmarks of cancer. Am. J. Cancer Res. 2017, 7, 1016-1036. [PubMed]

103. Aapro, M.S.; Plezia, P.M.; Alberts, D.S.; Graham, V.; Jones, S.E.; Surwit, E.A.; Moon, T.E. Double-blind crossover study of the antiemetic efficacy of high-dose dexamethasone versus high-dose metoclopramide. J. Clin. Oncol. 1984, 2, 466-471. [CrossRef]

104. Huang, W.J.; Bi, L.Y.; Li, Z.Z.; Zhang, X.; Ye, Y. Formononetin induces the mitochondrial apoptosis pathway in prostate cancer cells via downregulation of the igf-1/igf-1r signaling pathway. Pharm. Biol. 2013, 52, 466-470. [CrossRef] [PubMed]

105. Hu, W.; Xiao, Z. Formononetin induces apoptosis of human osteosarcoma cell line u2os by regulating the expression of bcl-2, bax and mir-375 in vitro and in vivo. Cell Physiol. Biochem. 2015, 37, 933-939. [CrossRef] 
106. Liu, X.J.; Li, Y.Q.; Chen, Q.Y.; Xiao, S.J.; Zeng, S.E. Up-regulating of rasd1 and apoptosis of du-145 human prostate cancer cells induced by formononetin in vitro. Asian Pac. J. Cancer Prev. 2014, 15, 2835-2839. [CrossRef] [PubMed]

107. Zhang, X.; Bi, L.; Ye, Y.; Chen, J. Formononetin induces apoptosis in pc-3 prostate cancer cells through enhancing the bax/bcl-2 ratios and regulating the p38/akt pathway. Nutr. Cancer 2014, 66, 656-661. [CrossRef] [PubMed]

108. Zhou, R.; Xu, L.; Ye, M.; Liao, M.; Du, H.; Chen, H. Formononetin inhibits migration and invasion of mda-mb-231 and $4 \mathrm{t} 1$ breast cancer cells by suppressing mmp-2 and mmp-9 through pi3k/akt signaling pathways. Horm. Metab. Res. 2014, 46, 753-760. [CrossRef] [PubMed]

109. Auyeung, K.K.; Law, P.C.; Ko, J.K. Novel anti-angiogenic effects of formononetin in human colon cancer cells and tumor xenograft. Oncol. Rep. 2012, 28, 2188-2194. [CrossRef] [PubMed]

110. Zhang, X.; Ni, Q.; Wang, Y.; Fan, H.; Li, Y. Synergistic anticancer effects of formononetin and temozolomide on glioma c6 cells. Biol. Pharm. Bull 2018, 41, 1194-1202. [CrossRef]

111. Liu, Q.; Sun, Y.; Zheng, J.M.; Yan, X.L.; Chen, H.M.; Chen, J.K.; Huang, H.Q. Formononetin sensitizes glioma cells to doxorubicin through preventing EMT via inhibition of histone deacetylase 5. Int. J. Clin. Exp. Pathol. 2015, 8, 6434-6441.

112. Qi, C.; Xie, M.; Liang, J.; Li, H.; Li, Z.; Shi, S.; Yang, X.; Wang, Z.; Tang, J.; Tang, A. Formononetin targets the mapk and pi3k/akt pathways to induce apoptosis in human nasopharyngeal carcinoma cells in vitro and in vivo. Int. J. Clin. Exp. Med. 2016, 9, 1180-1189.

113. Rosse, T.; Olivier, R.; Monney, L.; Rager, M.; Conus, S.; Fellay, I.; Jansen, B.; Borner, C. Bcl-2 prolongs cell survival after bax-induced release of cytochrome c. Nature 1998, 391, 496-499. [CrossRef] [PubMed]

114. Hu, W.; Wu, X.; Tang, J.; Xiao, N.; Zhao, G.; Zhang, L.; Ou, L. In vitro and in vivo studies of antiosteosarcoma activities of formononetin. J. Cell. Physiol. 2019. [CrossRef]

115. Montagut, C.; Settleman, J. Targeting the RAF-MEK-ERK pathway in cancer therapy. Cancer Lett. 2009, 283, 125-134. [CrossRef] [PubMed]

116. Luo, J.; Manning, B.D.; Cantley, L.C. Targeting the pi3k-akt pathway in human cancer: Rationale and promise. Cancer Cell 2003, 4, 257-262. [CrossRef]

117. Gelain, A.; Mori, M.; Meneghetti, F.; Villa, S. Signal transducer and activator of transcription protein 3 (stat3): An update on its direct inhibitors as promising anticancer agents. Curr. Med. Chem. 2018. [CrossRef]

118. Avalle, L.; Camporeale, A.; Camperi, A.; Poli, V. Stat3 in cancer: A double edged sword. Cytokine 2017, 98, 42-50. [CrossRef] [PubMed]

119. Lee, J.H.; Kim, C.; Lee, J.; Um, J.Y.; Sethi, G.; Ahn, K.S. Arctiin is a pharmacological inhibitor of stat3 phosphorylation at tyrosine 705 residue and potentiates bortezomib-induced apoptotic and anti-angiogenic effects in human multiple myeloma cells. Phytomedicine 2018, 55, 282-292. [CrossRef]

120. Jung, Y.Y.; Shanmugam, M.K.; Narula, A.S.; Kim, C.; Lee, J.H.; Namjoshi, O.A.; Blough, B.E.; Sethi, G.; Ahn, K.S. Oxymatrine attenuates tumor growth and deactivates stat5 signaling in a lung cancer xenograft model. Cancers 2019, 11. [CrossRef]

121. Wu, X.Y.; Xu, H.; Wu, Z.F.; Chen, C.; Liu, J.Y.; Wu, G.N.; Yao, X.Q.; Liu, F.K.; Li, G.; Shen, L. Formononetin, a novel fgfr2 inhibitor, potently inhibits angiogenesis and tumor growth in preclinical models. Oncotarget 2015, 6, 44563-44578. [CrossRef]

122. Baek, S.H.; Ko, J.H.; Lee, J.H.; Kim, C.; Lee, H.; Nam, D.; Lee, J.; Lee, S.G.; Yang, W.M.; Um, J.Y.; et al. Ginkgolic acid inhibits invasion and migration and tgf-beta-induced emt of lung cancer cells through pi3k/akt/mtor inactivation. J. Cell. Physiol. 2017, 232, 346-354. [CrossRef]

123. Mohan, C.D.; Srinivasa, V.; Rangappa, S.; Mervin, L.; Mohan, S.; Paricharak, S.; Baday, S.; Li, F.; Shanmugam, M.K.; Chinnathambi, A.; et al. Trisubstituted-imidazoles induce apoptosis in human breast cancer cells by targeting the oncogenic pi3k/akt/mtor signaling pathway. PLoS ONE 2016, 11, e0153155. [CrossRef]

124. Singh, S.S.; Yap, W.N.; Arfuso, F.; Kar, S.; Wang, C.; Cai, W.; Dharmarajan, A.M.; Sethi, G.; Kumar, A.P. Targeting the pi3k/akt signaling pathway in gastric carcinoma: A reality for personalized medicine? World J. Gastroenterol. 2015, 21, 12261-12273. [CrossRef] [PubMed]

125. Siveen, K.S.; Ahn, K.S.; Ong, T.H.; Shanmugam, M.K.; Li, F.; Yap, W.N.; Kumar, A.P.; Fong, C.W.; Tergaonkar, V.; Hui, K.M.; et al. Y-tocotrienol inhibits angiogenesis-dependent growth of human hepatocellular carcinoma through abrogation of akt/mTOR pathway in an orthotopic mouse model. Oncotarget 2014, 5, 1897-1911. [CrossRef] [PubMed] 
126. Kim, S.W.; Kim, S.M.; Bae, H.; Nam, D.; Lee, J.H.; Lee, S.G.; Shim, B.S.; Kim, S.H.; Ahn, K.S.; Choi, S.H.; et al. Embelin inhibits growth and induces apoptosis through the suppression of akt/mtor/s6k1 signaling cascades. Prostate 2013, 73, 296-305. [CrossRef] [PubMed]

127. Park, K.R.; Nam, D.; Yun, H.M.; Lee, S.G.; Jang, H.J.; Sethi, G.; Cho, S.K.; Ahn, K.S. Beta-caryophyllene oxide inhibits growth and induces apoptosis through the suppression of pi3k/akt/mtor/s6k1 pathways and ros-mediated mapks activation. Cancer Lett. 2011, 312, 178-188. [CrossRef] [PubMed]

128. Lee, J.H.; Kim, C.; Lee, S.G.; Yang, W.M.; Um, J.Y.; Sethi, G.; Ahn, K.S. Ophiopogonin d modulates multiple oncogenic signaling pathways, leading to suppression of proliferation and chemosensitization of human lung cancer cells. Phytomedicine 2018, 40, 165-175. [CrossRef] [PubMed]

129. Ko, J.H.; Nam, D.; Um, J.Y.; Jung, S.H.; Sethi, G.; Ahn, K.S. Bergamottin suppresses metastasis of lung cancer cells through abrogation of diverse oncogenic signaling cascades and epithelial-to-mesenchymal transition. Molecules 2018, 23, 1601. [CrossRef] [PubMed]

130. Lee, H.; Baek, S.H.; Lee, J.H.; Kim, C.; Ko, J.H.; Lee, S.G.; Chinnathambi, A.; Alharbi, S.A.; Yang, W.M.; Um, J.Y.; et al. Isorhynchophylline, a potent plant alkaloid, induces apoptotic and anti-metastatic effects in human hepatocellular carcinoma cells through the modulation of diverse cell signaling cascades. Int. J. Mol. Sci. 2017, 18, 1095. [CrossRef]

131. Kannaiyan, R.; Manu, K.A.; Chen, L.; Li, F.; Rajendran, P.; Subramaniam, A.; Lam, P.; Kumar, A.P.; Sethi, G. Celastrol inhibits tumor cell proliferation and promotes apoptosis through the activation of c-jun n-terminal kinase and suppression of pi3 k/akt signaling pathways. Apoptosis 2011, 16, 1028-1041. [CrossRef]

132. Sethi, G.; Ahn, K.S.; Sung, B.; Kunnumakkara, A.B.; Chaturvedi, M.M.; Aggarwal, B.B. Sh-5, an akt inhibitor potentiates apoptosis and inhibits invasion through the suppression of anti-apoptotic, proliferative and metastatic gene products regulated by ikappabalpha kinase activation. Biochem. Pharmacol. 2008, 76, 1404-1416. [CrossRef]

133. Ma, X.; Hu, Y. Targeting pi3k/akt/mtor cascade: The medicinal potential, updated research highlights and challenges ahead. Curr. Med. Chem. 2013, 20, 2991-3010. [CrossRef] [PubMed]

134. Dreher, D.; Junod, A.F. Role of oxygen free radicals in cancer development. Eur. J. Cancer 1996, 32A, 30-38. [CrossRef]

135. Arora, A.; Nair, M.G.; Strasburg, G.M. Antioxidant activities of isoflavones and their biological metabolites in a liposomal system. Arch. Biochem. Biophys. 1998, 356, 133-141. [CrossRef]

136. Kubota, Y. Tumor angiogenesis and anti-angiogenic therapy. Keio J. Med. 2012, 61, 47-56. [CrossRef]

137. Xiao, L.; Yang, S.; Hao, J.; Yuan, X.; Luo, W.; Jiang, L.; Hu, Y.; Fu, Z.; Zhang, Y.; Zou, C. Endostar attenuates melanoma tumor growth via its interruption of b-fgf mediated angiogenesis. Cancer Lett. 2015, 359, 148-154. [CrossRef]

138. Egeblad, M.; Werb, Z. New functions for the matrix metalloproteinases in cancer progression. Nat. Rev. Cancer 2002, 2, 161-174. [CrossRef]

139. Li, Y.; Cheng, H.S.; Chng, W.J.; Tergaonkar, V. Activation of mutant tert promoter by ras-erk signaling is a key step in malignant progression of braf-mutant human melanomas. Proc. Natl. Acad. Sci. USA 2016, 113, 14402-14407. [CrossRef] [PubMed]

140. Wang, Y.; Zhu, Y.; Gao, L.; Yin, H.; Xie, Z.; Wang, D.; Zhu, Z.; Han, X. Formononetin attenuates il-1beta-induced apoptosis and NF-kB activation in ins-1 cells. Molecules 2012, 17, 10052-10064. [CrossRef]

141. Duan, P.; Wang, Z.M. Clinical study on effect of astragalus in efficacy enhancing and toxicity reducing of chemotherapy in patients of malignant tumor. Zhongguo Zhong Xi Yi Jie He Za Zhi 2002, 22, 515-517.

142. Van den Bent, M.J.; Taphoorn, M.J.; Brandes, A.A.; Menten, J.; Stupp, R.; Frenay, M.; Chinot, O.; Kros, J.M.; van der Rijt, C.C.; Vecht Ch, J.; et al. Phase ii study of first-line chemotherapy with temozolomide in recurrent oligodendroglial tumors: The european organization for research and treatment of cancer brain tumor group study 26971. J. Clin. Oncol. 2003, 21, 2525-2528. [CrossRef]

143. Liu, X.; Fan, D. The epithelial-mesenchymal transition and cancer stem cells: Functional and mechanistic links. Curr. Pharm. Des. 2015, 21, 1279-1291. [CrossRef] [PubMed]

144. Su, Y.; Wang, J.; Zhang, X.; Shen, J.; Deng, L.; Liu, Q.; Li, G. Targeting sim2-s decreases glioma cell invasion through mesenchymal-epithelial transition. J. Cell Biochem. 2014, 115, 1900-1907.

145. Kalluri, R.; Weinberg, R.A. The basics of epithelial-mesenchymal transition. J. Clin. Investig. 2009, 119, 1420-1428. [CrossRef] [PubMed] 
146. watsuki, M.; Mimori, K.; Yokobori, T.; Ishi, H.; Beppu, T.; Nakamori, S.; Baba, H.; Mori, M. Epithelial-mesenchymal transition in cancer development and its clinical significance. Cancer Sci. 2010, 101, 293-299. [CrossRef] [PubMed]

147. Ren, J.; Xu, H.J.; Cheng, H.; Xin, W.Q.; Chen, X.; Hu, K. Synthesis and antitumor activity of formononetin nitrogen mustard derivatives. Eur. J. Med. Chem. 2012, 54, 175-187. [CrossRef]

148. Fu, D.J.; Zhang, L.; Song, J.; Mao, R.W.; Zhao, R.H.; Liu, Y.C.; Hou, Y.H.; Li, J.H.; Yang, J.J.; Jin, C.Y.; et al. Design and synthesis of formononetin-dithiocarbamate hybrids that inhibit growth and migration of pc-3 cells via mapk/wnt signaling pathways. Eur. J. Med. Chem. 2017, 127, 87-99. [CrossRef]

149. Lin, H.Y.; Sun, W.X.; Zheng, C.S.; Han, H.W.; Wang, X.; Zhang, Y.H.; Qiu, H.Y.; Tang, C.Y.; Qi, J.L.; Lu, G.H.; et al. Synthesis, characterization and biological evaluation of formononetin derivatives as novel egfr inhibitors via inhibiting growth, migration and inducing apoptosis in breast cancer cell line. RSC Adv. 2017, 7, 48404-48419. [CrossRef]

150. Li, Y.Q.; Yang, F.; Wang, L.; Cao, Z.; Han, T.J.; Duan, Z.A.; Li, Z.; Zhao, W.J. Phosphoramidate protides of five flavones and their antiproliferative activity against hepg2 and l-o2 cell lines. Eur. J. Med. Chem. 2016, 112, 196-208. [CrossRef]

151. Yang, C.; Xie, Q.; Zeng, X.; Tao, N.; Xu, Y.; Chen, Y.; Wang, J.; Zhang, L. Novel hybrids of podophyllotoxin and formononetin inhibit the growth, migration and invasion of lung cancer cells. Bioorg. Chem. 2019, 85, 445-454. [CrossRef]

152. Guo, B.; Liao, C.; Liu, X.; Yi, J. Preliminary study on conjugation of formononetin with multiwalled carbon nanotubes for inducing apoptosis via ros production in hela cells. Drug Des. Dev. Ther. 2018, 12, 2815-2826. [CrossRef]

153. Mu, H.; Bai, Y.H.; Wang, S.T.; Zhu, Z.M.; Zhang, Y.W. Research on antioxidant effects and estrogenic effect of formononetin from trifolium pratense (red clover). Phytomedicine 2009, 16, 314-319. [CrossRef] [PubMed]

154. Barrera, G. Oxidative stress and lipid peroxidation products in cancer progression and therapy. ISRN Oncol. 2012, 2012, 137289. [CrossRef] [PubMed]

155. Xing, D.X.; Liu, X.L.; Xue, C.K.; Huang, Q.; Liu, Z.G.; Xiong, L. The estrogenic effect of formononetin and its effect on the expression of rats' atrium estrogen receptors. Zhong Yao Cai 2010, 33, 1445-1449. [PubMed]

156. Bertolini, F.; Marighetti, P.; Martin-Padura, I.; Mancuso, P.; Hu-Lowe, D.D.; Shaked, Y.; D'Onofrio, A. Anti-vegf and beyond: Shaping a new generation of anti-angiogenic therapies for cancer. Drug Discov. Today 2011, 16, 1052-1060. [CrossRef] [PubMed]

157. Hao, Z.; Sadek, I. Sunitinib: The antiangiogenic effects and beyond. Oncol. Targets Ther. 2016, 9, 5495-5505. [CrossRef] [PubMed]

158. Fei, H.X.; Zhang, Y.B.; Liu, T.; Zhang, X.J.; Wu, S.L. Neuroprotective effect of formononetin in ameliorating learning and memory impairment in mouse model of alzheimer's disease. Biosci. Biotechnol. Biochem. 2018, 82, 57-64. [CrossRef]

159. Jarred, R.A.; Keikha, M.; Dowling, C.; McPherson, S.J.; Clare, A.M.; Husband, A.J.; Pedersen, J.S.; Frydenberg, M.; Risbridger, G.P. Induction of apoptosis in low to moderate-grade human prostate carcinoma by red clover-derived dietary isoflavones. Cancer Epidemiol. Biomark. Prev. 2002, 11, 1689-1696.

(C) 2019 by the authors. Licensee MDPI, Basel, Switzerland. This article is an open access article distributed under the terms and conditions of the Creative Commons Attribution (CC BY) license (http://creativecommons.org/licenses/by/4.0/). 